\title{
„Újra megtanultam önmagamban lenni”, avagy négy teljes hét Facebook nélkül
}

Kutatási jelentés, 2019

A tanulmányban bemutatott kutatás eredményei szerint a Facebook sokkal inkább pragmatikus információs platformként, mintsem közösségi kapcsolattartási felületként funkcionál felhasználóinak mindennapjaiban. Ezt tapasztalják legalábbis többségükben azok a felhasználók, akik felfüggesztik személyes Facebook-fiókjukat. Magyarországon a 2019. évi nagyböjt időszakában egy nyilvános felhívásra jelentkező 173 résztvevő négy hétig vállalt teljes Facebook-inaktivitás során naplózta tapasztalatait, amelyek részeként egyre növekvő felhasználói tudatosságról is beszámoltak. Az így kapott narratívákat a tanulmány kvalitatív tartalomelemző módszerrel elemezve mutatja be, kiemelve, hogy a mintavételben és az eredmények értelmezésében az önkéntességnek, azaz a résztvevők belső motivációjának igen fontos szerepe volt.

Kulcsszavak: közösségi média, social silence, Facebook-csend, Facebook-használat, felhasználói tudatosság, narratív elv

\section{A szerző(k)ről}

Mihalik Judit www.mihalikjudit.net

Így hivatkozzon erre a cikkre:

Mihalik Judit „Újra megtanultam magamban lenni, avagy négy teljes hét Facebook nélkül”, 


\section{Learned How To Stand Alone Again” - Four Full Weeks Without Facebook}

According to the findings of the empirical research presented in this paper, Facebook seemed instead a source of practical information than a social network platform for users. Leastwise, this is the function firstly recognized by those who inactivated their account. Participants, recruited by a public call in Hungary, 2019 Lent period, have been recorded their experiences related to the four week Facebook silence, showing more and more user consciousness during the session. Volunteering (as the self-motivation of the participants) appeared a dominant issue both concerning the results and to the interpretation as well. The narratives have been studied with a content analytics method.

Keywords: social media, social silence, quit Facebook, Facebook use, user cosciousness, narrative theory. 


\section{Bevezetés}

Jelen tanulmány egy empirikus kutatásról számol be, melyben önkéntesek vállalták, hogy négy hétre felfüggesztik a Facebook-fiókjukat, és a kísérlet részeként heti rendszerességgel naplózzák önmagukon tett megfigyeléseiket.

A kutatás elsődleges célja az volt, hogy az így előidézett hiányállapot rámutasson a közösségimédia-platform életünkben, mindennapjainkban betöltött szerepére, valamint szokásainkra, társas kapcsolatainkra, nyilvánosan vállalt és saját önképünkre gyakorolt hatására.

A kutatás járulékos célja a kapcsolódó elméletekben és empirikus kutatásokban (például Allcott et al. 2019, Portwood-Stacer 2013, Stieger et al. 2013) eddig feltárt jelenségek azonosítása, megerősítése és megvitatása.

Jelen vizsgálat tehát a kommunikációkutatások ama áramába illeszkedik, amely a hatásokra irányul, és ezen belül a felhasználói tudatosság, a digitális identitás és a személyes érzelmek egymásba kapcsolódó, egymást gyakran átfedő narratíváinak szövetében keres mintázatokat.

A kutatás közvetlen előzménye egy rendhagyó önkísérlet volt. Ennek keretében 2019 januárjában e tanulmány szerzője egy hónapra felfüggesztette saját Facebook-fiókját, és felismeréseiről nyilvános blogján, személyes hangú bejegyzésekben ${ }^{1}$ számolt be. A tapasztalatok adták számára a késztetést, hogy nagyobb minta alapján, szélesebb merítéssel vizsgálja meg a virtual identity suicide ${ }^{2}$ jelenségét, a kísérletet speciálisan a Facebook-használatra, azon belül pedig egy időszakos inaktivitásra fókuszálva. ${ }^{3}$

Az így koncipiált empirikus kísérlet 2019 márciusában zajlott, nagyböjt havában, hamvazószerdától virágvasárnapig. A kutatás ezért a Facebook Silence 2019 munkacímet kapta. ${ }^{4}$ Az időzítés nem volt véletlen, hiszen a közösségi médiától való tudatos, időszakos távolmaradást gyakran nevezik böjtnek vagy csendnek is. A résztvevők közül is többen akadtak, akik korábban már tartottak teljes vagy részleges digitális elvonulást ebben a tél végi időszakban.

\footnotetext{
1 A bejegyzések az alábbi linken érhetőek el: https://www.hrportal.hu/hrblog/humancafe/ongyilkossagom-tortenete-2-20190203.html (utolsó letöltés: 2019. 07. 05..)

2 Virtual identity suicide (más néven Web 2.0 suicide) néven emlegetik a digitális identitás, de elsősorban a közösségimédia-jelenlét időleges vagy inkább teljes megszüntetését. A szándékot számos internetes oldal is segítette az elmúlt évtizedben, például a www. http://www.suicidemachine.org/ vagy a tevékenységét beszüntetni kényszerült http://www.seppukoo.com/

3 Jelen tanulmány empirikus részében dr. Fehér Katalin társkutatóként vett részt. A szerző köszöni Demeter Márton, Herendy Csilla, Horányi Özséb, Kéri Rita, Rozgonyi Krisztina, Síklaki István, Szüts Zoltán és Török Judit támogatását.

4 A kutatásban való részvétel módja és egyben feltétele a fiók felfüggesztése volt, ezért jelen tanulmány is alapvetően ezt a kifejezést is használja. Ezenkívül szinonimaként ugyanezzel a jelentéssel az inaktivitás és a social silence, Facebook-silence, -csend kifejezések is előfordulnak a szövegben.
} 


\section{Kutatási előzmények}

Jelen kutatás szűk értelemben vett, közvetlenül releváns szakirodalmi háttere három csoportba rendezhető, csoportonként több ezres tételszámmal. Az első csoportot a hasonló, empirikus kísérletek kutatási jelentései alkotják. A második csoportba sorolhatók a Facebook-jelenség 5 társas és társadalmi, azaz szociálpszichológiai fókuszú elemzései. A harmadik csoportot pedig a jelenség megértéséhez fontos személypszichológiai vonatkozású tanulmányok és kutatások alkotják, mint például az identitás és a digitális identitás, illetve a személyiségtípusok és a közösségimédia-használat összefüggésének vizsgálatai.

A digital silence jelensége bő egy évtizede ismert, és közel ennyi ideje zajlanak vizsgálatok a közösségi média használatára, illetve tudatos nem használatára vonatkozóan is.

York és munkatársai (2015) megállapításai arra a fontos sajátosságra hívják fel a figyelmet, hogy a Facebook használatának időszakos felfüggesztésére nem érvényesek a technológiai innovációk használatára vonatkozó innovációs diffúzió elmélet (DOI) keretei, hiszen a Facebook-vakáció speciális esetként azt jelenti, hogy a felhasználók gyakran nem végleg, csak átmenetileg hagyják el a platformot. Az időszakos szüneten alapuló legfrissebb empirikus kísérletek közül való a Stanford Egyetem kutatóinak munkája (Allcott et al. 2019), amely közel háromezer fizetett résztvevő bevonásával azt igazolta, hogy a Facebook-fiókjukat a kísérlet részeként felfüggesztő felhasználók a vizsgálat egy hónapja idején kevésbé voltak tájékozottak a napi történésekről, ugyanakkor politikailag is kevésbé voltak polarizáltak és vehemensek, mint a résztvevők másik fele, akik továbbra is naponta legalább egy órát eltöltöttek a platform használatával ${ }^{6}$ Azokban a korábbi kutatásokban (például Stieger et al. 2013), amelyek az aktív és inaktív felhasználók értékrendjét, motivációit hasonlították össze, azt találták, hogy a saját elhatározásukból kilépők jelentős hányada adatvédelmi aggályok miatt hagyta el a platformot. Ugyanők magasabb értéket mutattak az internetfüggőséget illetően, de fontosabbnak érezték a magánéletük védelmét, mint a többiek.

Míg a Facebook-használat személyiségre, énképre gyakorolt negatív hatásait (megnövekedett stressz, szorongás) számos vizsgálat igazolta (például Luqman et al. 2017), a kilépés vagy felfüggesztés hatásait közvetlenül vizsgáló kutatások Turel összegzése (2015) szerint általában azt találták, hogy a Fa-

\footnotetext{
5 A tanulmánynak nem tárgya az internethasználat és a közösségimédia-használat trendjeinek bemutatása. A munkához áttekintett és háttérként felhasznált tényadatokat itt lehet megtalálni: https://wearesocial.com/blog/2019/01/digital-2019-global-internet-use-accelerates és http://nmhh.hu/dokumentum/202180/lakossagi internethasznalat 2018.pdf Utolsó letöltés: 2019 07. 21.

6 A Stanford-kutatásban a résztvevők díjazását (102 USD/résztvevő/hónap) egy másik, korábbi kutatás (Corrigan et al. 2018) alapján határozták meg, amely szerint az amerikai felhasználók átlagosan 1000 dollárért hajlandóak egy teljes évre felfüggeszteni a Facebook-használatukat.
} 
cebookot inaktiválók jobb közérzetről, nyugodtabb mindennapokról, javuló önértékelésről, kiegyensúlyozottabb kedélyről számoltak be, akár már egy hét után is.

A platformtól való időszakos vagy teljes távolmaradás értelmezhető egyfajta fogyasztói kritikai magatartásként is (Portwood-Stacer 2013), másképpen a tudatosság és ellenállás elitista választásaként, amely egy ma még szűk, de egyre bővülő kört jellemez. Baumer és munkatársai (2013) négyszáz résztvevő segítségével vették szemügyre a Facebook elhagyásának okait és motivációit, és - a többi közt - arra következtettek, hogy a hozzáférés felfüggesztése vagy megszüntetése kifejezetten deviáns viselkedésnek minősülhet a maradók körében, így ez a cselekedet a szerzők szerint stigmatizál. Ezzel ellentétes következtetésre jutott azonban egy újabb magyar kutatás (Újhelyi-Domonkos 2016), amely - más szempontok mellett - a felhasználók és nem használók kölcsönös percepcióit mérte. A kutatópáros azt is igazolta, hogy a két csoportra érvényesek a csoportképző és csoportkohéziót támogató megerősítési torzítások, vagyis kölcsönösen meglehetősen hasonló (negatív) mintázat szerint ítélik meg a másik csoport tagjait, míg saját csoporttársaikat mindkét csoport tagjai pozitívabb tulajdonságok hordozóinak látják. Ezek a kutatások már részben a szakirodalom azon tartalmaihoz sorolhatók, amelyek a közösségi média társas és társadalmi relevanciáihoz kapcsolhatóak, igen jelentős korpuszt alkotva. Egy összehasonlító elemzés szerint (Wilson, Gosling, Graham 2012) a Facebook-jelenséget kutatók közel harmadát kifejezetten a platform használatának társas kapcsolatainkat befolyásoló hatása érdekli, a többi kutatás pedig megoszlik a sok egyéb aspektus között.7 A jelenséget az egyéni felhasználók szempontjából vizsgálva a Facebookon való jelenlét értelmezését alapvetően a használat és szükségletkielégítés elmélete ${ }^{8}$ keretezi. A platform mint a nyilvános énkép és ezen belül a digitális identitás formálásának, manifesztációjának egyik legfontosabb jelenlegi felülete számtalan kutatás tárgya. ${ }^{9}$

7 A szociálpszichológiai aspektusokat magyar nyelven Újhelyi Adrienn (2014) tanulmánya kitűnően összefoglalja.

8 A Uses and Gratifications elméletnek számos változata és kiterjesztése létezik, az egyik eredeti forrás: Katz, Gurevitz és Haas 1973

9 Terjedelmi okokból csak néhány fontosabb magyar empirikus kutatást említünk meg itt a közelmúltból. A függőséget a narcisztikus és neurotikus személyiségjegyek kontextusában Dávid Balázs és Körmendi Attila (2018) vizsgálta. A mentális alkat, az önértékelési kontingenciák és a Facebook-használat kapcsolatának megértéséhez Tóth József és Mirnics Zsuzsanna (2014) járult hozzá egy fiatalokkal végzett empirikus kutatással. A nyilvános én-üzenetek klasszifikációját Szűts Zoltán (2013) végezte el. A nemzetközi kontextusból itt csak az egyik legfrissebb összefoglalót (Amandeep et al. 2018) emeljük ki, amelyben a szerzők a korábbi kutatások áttekintése után szintén arra jutnak, hogy leginkább azok kitettek például a FoMO (Fear of Missing Out - kimaradástól való félelem) jelenségének, akik egyébként is labilis mentális állapotban vannak, és/vagy kevéssé elégedettek az életükkel. Kutatásuk azt igazolta, hogy a kényszeres használat összefüggésbe hozható a közösségimédia-fáradtság néven azonosított jelenséggel. 


\section{A kutatás és elemzés módszere}

A kutatás résztvevői nyilvános online platformokon (Index.hu, Filter.hu, HR Portál Blogger) ${ }^{10}$, valamint a Facebook különféle felületein és levelezőlistákon közzétett felhívásokon át jelentkezhettek, amelyben egy link a kutatási adatgyüjtéshez használt Google Forms kérdőívre mutatott. ${ }^{11}$ A résztvevők első feladata az volt, hogy a jelentkezési kérdőív kitöltése után függesszék fel Facebook-fiókjukat. A Messenger alkalmazás használatából nem kellett kizárniuk magukat. Ennek oka, hogy mára a Messenger használata a Facbook-jelenléttől függetlenné vált, fontos és önálló kommunikációs csatornaként tekintünk rá. Másrészt a kutatás célja nem az összes Facebook alkalmazásra irányult, hanem kifejezetten a Facebook közösségi média funkciójára, így az alapvetően üzenetküldésre használt eszköztől értelmetlen és felesleges lett volna megfosztani a résztvevőket. A kísérlet kezdetén azonban a többség eszközeiről a Facebook alkalmazást is eltávolította, néhányan pedig egyenesen a fiókjuk törlését kezdeményezték, saját elhatározásukból.

\section{Az adatfelvétel módszere}

Az adatfelvétel két feleletválasztós teljes kérdőívsort, valamint négy nyitott, bármilyen terjedelemben megválaszolható kérdést (a „visszajelzések” kérdései) foglalt magába. Ezenkívül az első, a második és a harmadik heti visszajelzéshez tartozott még egy-egy feleletválasztós kiegészítő kérdés is. A kérdőíveket a kutatás kezdetén (28 tételből álló kérdőív) és végén (18 tételből álló kérdőív) töltötték ki, míg a visszajelzésekhez (avagy naplózáshoz) segítséget adó kifejtendő kérdéseket a fiók felfüggesztésének első, második, harmadik és negyedik hetének végén kapták meg a résztvevők. A heti visszajelzések elküldésére rendre öt nap állt a résztvevők rendelkezésére, amelyben egy hétvége is benne foglaltatott.

\section{A résztvevők}

A jelentkezés rögzítésekor kitöltött kérdőívek tanúsága szerint a 173 résztvevő többsége erős személyes motivációval rendelkezett a Facebook-jelenlé-

\footnotetext{
10 https://index.hu/mindekozben/poszt/2019/03/07/kiprobalnad milyen az elet facebook nelkul/ (utolsó leöltés 2019. 07.10) és https://www.filter.hu/cikkek/1044/van-e-elet-a-facebookon-tul?fbclid=IwAR1-Q63mPwq6-mtoezgjLGSnZuXJ3Y qM2mh5gpT5eNSCVsPzQxc1YJG7ns (utolsó leöltés 2019. 07.10) és https://www.hrportal.hu/hrblog/humancafe/van-e-elet-a-facebookon-tul 63 -20190305.html (utolsó leöltés 2019. 07.10)

11 A kérdőív nem tartalmazott kérdést arra vonatkozóan, hogy milyen forrásból értesült a résztvevő a felhívásról, de mivel a megjelenések nem egy időben történtek, az egyes kérdőívek beküldési ideje alapján következtethető, hogy többségük (a 173 főből körülbelül 150 fő) nem a Facebook felületéről érkezett.
} 
tének szüneteltetésére. Ezért a minta hangsúlyozottan nem reprezentatív a Facebook teljes felhasználói populációjára, sokkal inkább azokról a felhasználókról referál, akik Facebook-jelenlétüket már a kísérlet előtt is kritikai reflexióval szemlélték. A jelentkezők jórészt fiatal, városi, magasabb iskolai végzettségü, alkalmazotti státuszú személyek voltak, többségük már régóta fontolgatta, hogy időlegesen vagy véglegesen megszünteti a jelenlétét a platformon, ${ }^{12}$ illetve már rendelkezett hasonló közvetett vagy közvetlen tapasztalattal a hozzáférés felfüggesztéséről. Így a minta nem csupán demográfiai értelemben nem reprezentatív, hanem azért sem, mert a felhívás eleve azokat szólította meg, akik már korábban is kifejezetten erős motivációt éreztek a Facebook elhagyását illetően - a felhívás tulajdonképpen csak megerősítette szándékukat, és kihívást láttak benne. Bár ez a kitétel (a belülről motivált résztvevői kör) nem volt része sem az eredeti kutatási koncepciónak, sem a résztvevők toborzásának, alább látható lesz, hogy az eredmények szempontjából nagy jelentőséggel bír. Hasonlóan lényeges az a megvitatást érdemben befolyásoló körülmény, hogy a kutatásban való részvétel anonim, önkéntes, és főként: díjazás nélküli volt. ${ }^{13} \mathrm{~A}$ jelentkezéskor kitöltött kérdőívben a részvételi motiváció iránt érdeklődő kérdésre adott válaszok szerint (1. ábra) a többség valamilyen határozott személyes céllal vágott bele a kísérletbe.

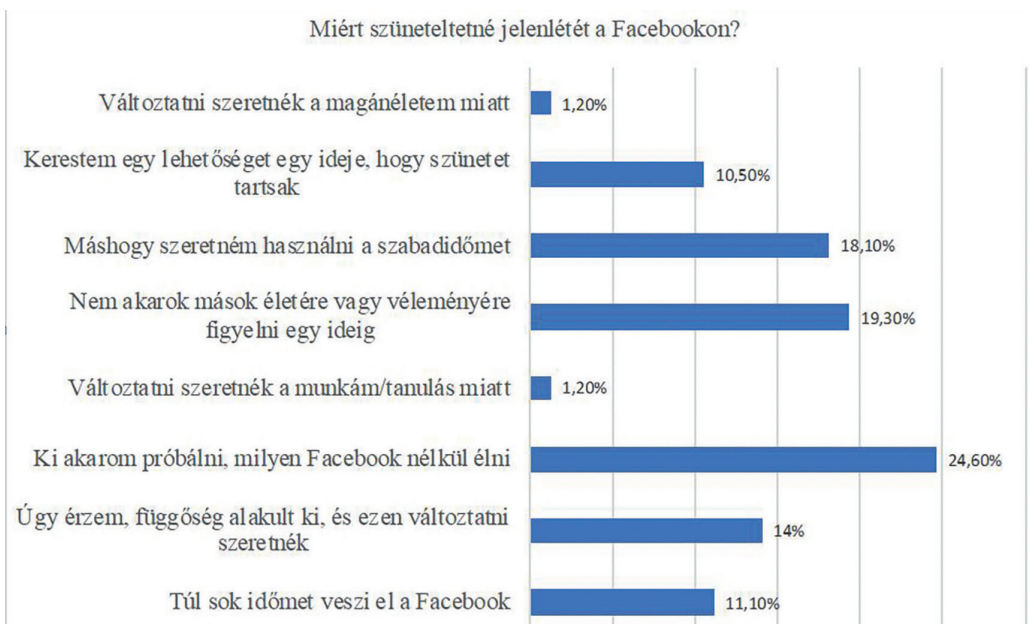

1.ábra: „Miért szüneteltetné jelenlétét a Facebookon?” N=173

\footnotetext{
12 A résztvevők demográfiai adatait a Függelék tartalmazza.

13 Metodológiai szempontból már itt fontos felhívni a figyelmet a motiváció és javadalmazás összefüggésére, például Dan Ariely (2016) vizsgálataira. A viselkedési közgazdaságtan kimutatta, hogy egyes feladatok esetében a pénzbeli jutalom és a motiváció gyakran fordított öszszefüggésben áll, mert a pénz demotiváló stresszfaktorként is megjelenhet. Azaz egy ehhez hasonló kísérlet esetében is különbség lehet egy belsőleg motivált, díjazás nélküli, önkéntes résztvevőkkel végrehajtott vizsgálat és egy másik között, ahol a résztvevők hasonló feladat teljesítéséért javadalmazást kapnak.
} 
Az egyes hetekben aktív, tehát visszajelzést küldő résztvevők száma 108 fő és 83 fő között ingadozott. ${ }^{14}$ Mindösszesen négy olyan résztvevő volt, aki az első kérdőív kitöltése után e-mailben jelezte, hogy kilép a kísérletből.

A visszajelők száma az alábbiak szerint változott:

- a jelentkezési kérdőív kitöltői: 173 fő ( $\mathrm{N}=173)$;

- adattisztítás: 4 fő kilépett a kísérletből;

- első hét után aktív (visszajelzők száma): 108 fő (N=169);

- második hét után aktív: 83 fő (N=169);

- harmadik hét után aktív: 86 fő ( $\mathrm{N}=169)$;

- negyedik hét után aktív és egyben a kutatást záró kérdőívet kitöltők száma: 87 fó $(\mathrm{N}=169)$.

A jelen tanulmány tárgyát képező narratív adatfelvételhez a négy héten át hasonló, szövegszerűen is majdnem azonos, nyitottkérdés-csoportot szolgált támpontul, minél nagyobb teret hagyva az egyéni hangvételnek, személyes fókusznak, habitusnak, stílusnak, tartalmi és terjedelmi ízlésnek. A kérdésekre adott válaszok hossza ennek megfelelő változatosságot mutatva egyenként 49-től 2170 karakterig terjedt. A négy hét során kapott visszajelzések, azaz a teljes szövegkorpusz összesen közel 20 ezer szó terjedelmet tesznek ki.

Az első hét utáni visszajelzést kérő kérdéscsoport így szólt:

Kérjük, alább írjon hosszabban, akár személyes hangon is az első hét tapasztalatairól. Minden részlet érdekel bennünket. Milyen érzés volt felfüggeszteni a fiókját? Nehéz volt-e betartani a szünetet eddig? Voltak-e új élményei társas kapcsolataiban, mindennapjaiban? Változtatott-e életmódján, szokásain? Volt-e hiányérzete? Mi volt a legmeghatározóbb tapasztalat az első napokban? Bármilyen hosszan válaszolhat. A válaszokat név nélkül kezeljük.

A további hetek kérdései ennek a kérdéssornak a mutációi (a tartalmat nem érintő változatai) voltak.

\section{Az elemzésbe bevont adatok}

Jelen tanulmány célkitűzése a kutatási adatfelvételen belül kifejezetten a nyitott kérdésekre adott szöveges visszajelzések (azaz a résztvevői tapasztalatok heti rendszerességű naplózásának) feldolgozása, a kvantitatív jellegű kérdőívekben kapott válaszokból csak a narratívák analízisének alátámasztására szolgáló néhány fontos elemet megmutatva. Elsősorban azért, mert a kísérletet nyitó és záró feleletválasztós kérdéssorok főként az online jelenlét módjára

14 Bár a visszajelzések egyenetlen száma egyfelől az önkéntesség hátrányának bizonyult, a narratív szemléletnek nagyon is megfelel, hogy csak akkor naplózzon a résztvevő, amikor úgy érzi, hogy valóban közlendője van. Mivel az egyes hetek naplózása anonim módon történt, a választott módszerből következően a válaszok nem köthetők a válaszadókhoz. Ezért nem validált, hogy összes résztvevő ( $\mathrm{N=173)}$ közül pontosan kik voltak aktívak az egyes heti visszajelzésekben. 
és a szociális média használatára vonatkoztak, és a talált eredmények nem mutatnak túl a már publikált, korábbi, többnyire nagyobb és reprezentatívabb, a kvantitatív kutatások módszertani szabályainak megfelelő mintákon kapott hazai és nemzetközi kutatási eredményeken. Bár megerősítik azokat, jelentős különbség nem tapasztalható, azaz ez a vállalkozás új tudományos eredményekkel nem kecsegtetne, ráadásul az eredmények nem is reprezentatívak. Ezzel szemben, a nyitott kérdésekre adott válaszok, vagyis heti rendszerességű naplózás során keletkezett nagy mennyiségű, szöveges adattömeg, valamint a kutatásban részt vevők - alább bemutatandó - sajátos összetétele jóval árnyaltabb kvalitatív elemzésre és eredeti, tudományos újdonságot is jelentő következtetésekre adtak lehetőséget.

\section{A tartalomelemzés módszere}

Az adatok feldolgozása kvalitatív tartalomelemzéssel történt. ${ }^{15} \mathrm{~A}$ módszer célja, hogy kategóriák megalkotásával a szöveg mélyebb rétegeiben fellelhető témákat azonosítsa, azok gyakoriságából és egymáshoz viszonyított tartalmaiból következtetni lehessen a hangsúlyokra, azaz a résztvevők mentális és kognitív folyamataira. Bár az adatfelvételi módszerből következően a visszajelzések gazdag anyagot tartalmaznak más diszciplináris fókuszú vizsgálathoz is, az elemzés azokra - a kommunikációkutatásban releváns - reflexiókra koncentrál, amelyek a platform használatának közvetlen narratívái. Így az analízis jellemzően nem tartalmazza például azokat az utalásokat sem, amelyek a szokásokkal, berögződésekkel és azok reflexióival foglalkoznak.

A szöveg kódolása hatelemű kódrendszer („témák”) segítségével történt gondolati szekvenciákat keresve, azaz bekezdés és mondat szinteken. Egy résztvevő egy-egy heti visszajelzése maximálisan négy különféle kódot kaphatott, tartalomtól és terjedelemtől függően. A kódolás tudományos megbízhatóságát ${ }^{16}$ egy társ-elemző bevonása biztosította, aki a kódok részletes leírása (kódkönyv) alapján dolgozott.

A kódok induktív úton keletkeztek. Első körben egy előzetes sejtés mentén kialakított négy kategória („praktikum”, „veszteségek”, „nyereségek”, „tudatosság”) bővült a második körben hateleműre. A „nyereségek” kód utóbb kettévált, és egy „érzelmek” kód is szükségesnek mutatkozott. ${ }^{17}$ A nyers adatok szövegkorpuszából így létrejött hat csoporton belül ezután további tematikus

15 Krippendorff (2018) nyomán.

16 A kódolási egyezőség (Forman és Darmschroder 2008) ellenőrzését Herendy Csilla társelemző segítsége biztosította. Ennek során egy adatsor párhuzamos kódolása történt a kódszavak részletesen megadott és példákkal is értelmezett definíciói mentén. A kódolás egyezősége 83\% volt, azaz megfelelt a kívánatosnak tartott (Miles és Huberman 1994) legalább 80\%-0s mértéknek.

17 A kódok jelentésének részletezése az elemzésben található. 
osztályozás következett (a témákon belüli „mintázatok” azonosításával). Az elemzés e témákat és mintázatokat követi (1. ábra).

\begin{tabular}{|c|c|c|}
\hline \multicolumn{3}{|c|}{ A narratívákban a kódolás során azonosított témák és mintázatok } \\
\hline Téma & Leírás & Mintázatok \\
\hline Praktikum & $\begin{array}{l}\text { A mindennapi élet, a társas és } \\
\text { közösségi kapcsolatok megszerve- } \\
\text { zéséhez, programokhoz kapcsolódó } \\
\text { kommunikáció és információgyüjtés }\end{array}$ & $\begin{array}{l}\text { - csoportokban folyó kommuni- } \\
\text { káció } \\
\text { • zárt események } \\
\text { • információgyűjtés emberekről, } \\
\text { jeles alkalmak emlékeztetői } \\
\text { • családi kapcsolattartás, „family } \\
\text { news” csatornák } \\
\text { - kiegészítő alkalmazások }\end{array}$ \\
\hline Veszteségek & $\begin{array}{l}\text { Fontos, máshol ugyanebben a } \\
\text { formában nem megélhető vagy } \\
\text { hozzáférhető tapasztalatok, tartal- } \\
\text { mak, kommunikációs lehetőségek, } \\
\text { tevékenységek vagy impulzusok. }\end{array}$ & $\begin{array}{l}\text { - magányérzet erősödése } \\
\text { - identitásképző csoportok és kap- } \\
\text { csolatok elvesztése } \\
\text { - földrajzi távolság miatti elszige- } \\
\text { teltség érzete }\end{array}$ \\
\hline $\begin{array}{c}\text { „Offline” } \\
\text { nyereségek }\end{array}$ & $\begin{array}{l}\text { A felfüggesztéshez kapcsolódó } \\
\text { életmód-változások kísérői: a } \\
\text { napirendet, tevékenységeket, az } \\
\text { időbeosztást és/vagy a kapcsolatokat } \\
\text { lényegileg érintő reflexiók. }\end{array}$ & $\begin{array}{l}\text { - emberi kapcsolatok valós } \\
\text { tér-időben } \\
\text { - aktív cselekvés } \\
\text { - átértékelt kapcsolatok } \\
\text { - új tevékenységek felfedezése és } \\
\text { újrafelfedezése }\end{array}$ \\
\hline $\begin{array}{c}\text { „Online” } \\
\text { nyereségek }\end{array}$ & $\begin{array}{l}\text { Azok a mintázatok, amely az online } \\
\text { térben a reflektált, tudatos választás } \\
\text { szabadságának megélését jelzik. }\end{array}$ & $\begin{array}{l}\text { - kitörés a filter buborékból }{ }^{18} \\
\text { - reflektált, tudatos látókör-bővítés } \\
\text { - platform-multiplikáció, hangsúly- } \\
\text { váltás }\end{array}$ \\
\hline Tudatosság & $\begin{array}{l}\text { Önálló témaként a tudatosság nö- } \\
\text { velésének igénye és/vagy a függő- } \\
\text { ség-élmény azonosítása. }\end{array}$ & $\begin{array}{l}\text { - időhasználat, időfecsérlés } \\
\text { - unalom } \\
\text { - mobil eszközök kéznél-lévősége } \\
\text { - szokások reflektív szemlélete } \\
\text { - önreflexió, társas kapcsolatok } \\
\text { kritikai szemlélete } \\
\text { - virtuális tér és idő értelmezése }\end{array}$ \\
\hline $\begin{array}{c}\text { Érzések és } \\
\text { érzelmek }\end{array}$ & $\begin{array}{l}\text { Az egészen személyes vonatkozású } \\
\text { reflexiók, a társas kapcsolatok érté- } \\
\text { kelése és átértékelése, valamint az } \\
\text { ezekkel kapcsolatos beszámolók. }\end{array}$ & $\begin{array}{l}\text { - nyugalom, elcsendesülés, zajcsök- } \\
\text { kenés } \\
\text { • szorongás, stressz, fáradtság és } \\
\text { frusztráció-szint } \\
\text { - függőség és önrendelkezés }\end{array}$ \\
\hline
\end{tabular}

1. táblázat: a kódolás során azonosított témák és mintázatok (a kódkönyv kivonata)

18 A „Filter Bubble” elnevezést többféleképpen fordítják a magyar szakirodalomban. Ebben a szövegben következetesen a filter buborék kifejezést használom. 


\section{Eredmények}

Az eredmények ismertetése két részre bontható. Elsőként a kódolt témákat és a témákon belüli mintázatokat érdemes bemutatni, a résztvevők visszajelzéseinek tematikusan rendezett narratíva-korpuszából származó szó szerinti idézetekkel illusztrálva. ${ }^{19}$ Ezután a témák előfordulásának heti tendenciáit célszerű megszemlélni. Bevezetésképp azonban fontos a Facebook-fiók felfüggesztésével kapcsolatos résztvevői várakozásokról és élményekről is szót ejteni.

\section{A felfüggesztés tapasztalatai}

„Egyáltalán nem volt nehéz. Vártam valami katarzis-szerüt, hogy majd hősiesen küzdök, csaknem elbukom, de aztán mégsem, és vonósok, de az igazság az, hogy tökre simán ment minden."20

„A felfüggesztést megelőző délután hosszan időztem a Facebookon, mintha nagy veszteségre készülnék, nézegettem a hírfolyamot: uhh, mi mindenrölfogok lemaradni."

Mivel a fiók felfüggesztésével (azaz magával a „digital silence” jelenséggel) közvetlenül összefüggő, a fentiekhez hasonló általános várakozások és tapasztalatok nem tárgyai jelen beszámolónak, ezért ezek a reflexiók nem is kaptak kódot. Az ezzel kapcsolatos visszajelzésekből érzékelhető tendenciák fő vonalai azonban említést érdemelnek.

Sokan jelezték vissza például a csendélményt: „én nagyon nagy megkönynyebbülésként kezelem a Facebook-fiókom felfüggesztését”.

A többség úgy érezte, hogy korántsem volt olyan nehéz a Facebook nélküli élet, mint várta. „Semmiféle fennakadást nem okozott. Időnként rákattintottam volna, de csak megszokásból.”

Számos válaszadó azonosította ugyanakkor, hogy a platform használata részévé vált a napi rutinjának, például a reggeli kávé mellett, várakozáskor vagy munkába menet. „Az első egy-két napban azt vettem észre, hogy nagyon gyakran, olyan 10-15 percenként nyúlok reflexszerüen a telefonomhoz, hogy megnézzem a Facebookot, mire hozzászoktam, hogy nem tudok bejelentkezni. A harmadik naptól már teljesen megszoktam, és örömmel tapasztaltam, hogy eszembe sem jut a telefon."

Többen hasonlították benyomásaikat a szenvedélybetegségekkel való küzdelemhez.

19 A közel 20 ezer szóból álló korpuszból ez a tanulmány mintegy 3200 szó terjedelemben tartalmaz idézeteket.

$20 \mathrm{Ez}$ a tanulmány a résztvevőktől kapott visszajelzések szövegét dőlt betűvel, idézőjelben, anonim módon, változtatás nélkül tartalmazza, kizárólag az értelemzavaró, nyelvhelyességi vagy gépelési hibákat javítva. 
„Szinte olyan volt az önmegtartóztatás érzése, mint a cigarettáról való leszokáskor.”

„Nem tudtam szabad pillanataimban mit kezdeni a kezeimmel a szó szoros értelmében.”

Néhányan beszámoltak arról is, hogy korábbi kilépési kísérleteik azért nem sikerültek, mert ezzel elzárták magukat fontos, más módon nem elérhető információforrásoktól. „Már megpróbálkoztam ezzel a felfüggesztéssel 2-3 évvel ezelőtt, de sajnos az emberek annyira függnek ettől a közösségi oldaltól, hogy nem tudtam végigcsinálni, vissza kellett csinálnom, mert a középiskolában (!!!) a tanárnőm számon kérte, hogy mi az, hogy én nem használom a Facebookot?!”

A válaszadók között nagy számban akadtak olyanok, akik már a kísérletet megelőzően is korlátozták a platformon töltött felhasználói időt: „napi 10 percet engedélyeztem a Stay Focused nevü Chrome-kiegészítővel”.

A felfüggesztés során néhányan új viszonyba kerültek az önfegyelemmel is. „Annyi változás van, hogy ha otthon vagyok egyedül, és valami nemszeretem munkát kell csinálnom, például kitakarítani a fürdőszobát, akkor gyorsabb és hatékonyabb vagyok, mert nem nézem meg közben ötször, hogy hányan kommenteltek a legutóbbi posztomhoz.”

Mások pedig - különféle módokon - azt nyilatkozták, hogy a korábban feszültség levezetésére használták a felületet. „Számomra a FB kicsit olyan, mint a mesebeli szegénylegénynek az ürgelyuk a mezőn: valahova bele kell «kiabálnom « a dolgaimat néha, és most bizony hiányzik az eszköz a ventilláláshoz.”

\section{Témák és mintázatok}

Az alábbiakban az egyes kódolt témák bemutatása következik. Mottóként minden témát rendre egy-egy jellegzetes visszajelzéssel exponálva, majd definiálva a kódot, annak értelmezését, végül pedig a narratívát a témán belül fellelt mintázatok szerint rendezve, ismét idézve néhány tipikus vagy épp rendhagyó szövegrészletet.

\section{Praktikum}

„A kislányom néptánccsoportja rendszeren a Facebook-csoportban oszt meg információt időpontokról, vagy ha esetleg elmarad egy-egy óra. Ezenkívül az óvodában a szülői munkaközösséget vezetem, ott is van egy Facebook-csoportunk, ahol sokszor én vagyok, aki megosztja a fontos infókat, erre a szerepre most megkértem a férjem. Plusz így a futóklubunk infóit is máshonnan kellett beszereznem, ami megnehezítette az életem.”

A „praktikum” témához tartozik mindaz, ami a mindennapi élet megszervezéséhez, társas és közösségi kapcsolatok menedzseléséhez, programokhoz, információcseréhez kapcsolódik, azaz minden olyan kommunikációs folyamat, ahol a platform inkább eszköz, mint cél. A kutatásban résztvevők számos kellemetlen meglepetésről, nehézségről számoltak be, főként az első napok után. 
Az észlelt praktikus nehézségek első, legnépesebb csoportját a csoportokban közzétett információk hiánya jelentette. Sokan bizonyos kérdésekben elsődleges vagy akár kizárólagos információ- vagy hírforrásként, illetve kommunikációs csatornaként használják a platformot. Tipikusan ilyen felületnek számítanak a nyílt vagy zárt csoportok, ahol a tagok egy adott tevékenység, közösség vagy élethelyzet mentén érintettjei az információknak.

„Az első probléma az ebédmenüvel volt, de abban segítségemre volt egy kollégám. Hétfön már magától elküldte e-mailben az egész heti menüt. :)”

„Nincs lehetőségem információt gyüjteni szolgáltatókról, példálul nem látom az éttermek menüajánlatait és akcióit. A Facebookon szoktam utánajárni új szolgáltatásoknak is mint fodrász vagy táncoktatás, így most kicsit vakon tapogatózom ezekkel kapcsolatban.”

„Ưgy éreztem, hogy a felmerülő kérdéseket nem tudom kitől megkérdezni ( például virágültetés, hulladékmentes megoldások stb.), ezekre a kérdésekre mindig a FB-csoportokban kerestem a választ.”

„A legrosszabb talán az, hogy az iskolai munkámban is hátráltat ez a kísérlet, mivel a tanárom a Facebookos csoportban osztja meg az infókat, így én ezen a héten késve tudtam meg dolgokat, hiszen senki se gondolná, hogy ne használnám a Facebookomat.”

„A gyermekeim osztálya valamint a saját iskolatársaim is FB-n keresztül kommunikálnak."

„A tananyagokat nem mindig tudtam időben beszerezni, így ezen a héten puffogva aktiváltam a fiókomat, és letöltöttem a tananyagot. Milyen világ az, ahol a Facebookot kell használni az iskola miatt?”

„Tanár vagyok, és egy tanulócsoportomat így nem látom. Jó lenne képben lenni, hogy hol tartanak, van-e valami új problémájuk, értik-e, hogy miröl volt szó utoljára. Áthidaló megoldásként egy diákomat kértem meg, hogy Messengeren értesítsen, ha van valami, amiről tudnom kéne.”

A másik jellegzetes nehézséget a zárt körü társasági események, közös szervezésü programok alkotják. Szinte minden válaszadó megemlített valami hasonlót.

„Nos, rájöttem, hogy a külföldi csoportos kiutazás elött egy nappal megszüntetni az egyik legsimább kapcsolattartási platformot nem a legjobb döntésnek bizonyult. Ennek ellenére sikerült minden kommunikációt zökkenőmentesen lebonyolítani, maximum kimaradok a kiutazó csapat «melyik éttermet érdemes elkerülni» jellegü vitájából.”

„Nem várt nehézség, hogy a huszonöt éves osztálytalálkozót Facebook-eseményként kezdték szervezni. Szerencsére megkerestek Messengeren is, de zavar, hogy nem tudok hozzászólni az eseménynél a társalgáshoz.”

„A Facebookos osztálycsoporton keresztül szervezzük a ballagással és szerenáddal kapcsolatos dolgokat és megijedtem, hogy ez esetleg hátráltatni fog."

A fentiekhez képest kevesebben jelezték vissza a nyilvános rendezvények és azok változáskövetésének nehézségeit. Valószínűleg azért, mert ezek az események általában regisztráció nélkül is megtalálhatóak az interneten. Igaz, a részvételi hajlandóságot általában befolyásolja, hogy az aktív felhasználók 
előzetesen ellenőrizhetik, vannak-e ismerőseik a jelenlétüket visszajelzők között, azaz egyfajta „szociális” buborék-elv érvényesül.

„Nem tudok felmenni megnézni a hét eseményeit (kiállítás megnyitókat az aktuális bulikat, workshopokat, túrákat, vásárokat, alulról szerveződő eseményeket)."

Sok visszajelzésben bukkant fel viszont a társas kapcsolattartás, illetve szociális háló valamilyen praktikus kontextusa.

„Pár alkalommal rá szerettem volna keresni egy-két emberre (munka miatt, régi csoporttárs stb.), de ezt ugye nem tudtam megtenni.”

„A helyzetem három héten belül épp álláskeresőre változik, itt például nagy segítség lehetne egyesek szerint a FB. "21

„Kellemetlen volt, hogy elfelejtettem egy régi barátom szülinapját, mert nem kaptam Facebook-értesitést."

„Megrögzött agglegényként sokat ismerkedem. Gyorsan rá kellett jönnöm, hogy senkire nem tudok rákeresni, megnézni, kiről is van szó. Illetve kétszer is elöfordult, hogy akivel megismerkedtem, telefonszámot nem akart adni, hanem a Facebookot preferálta, és megkért, hogy jelöljem be. Mikor kiderült, hogy nincs Facebookom, hitetlenkedve leráztak.

Reflektáltak arra is, hogy a platform szolgáltatásai már észrevétlenül átalakították az új kapcsolatokat befolyásoló első benyomásainkat is.

„A Facebook-csend 3. hetében egy fiú elhívott randizni, és míg korábban ilyenkor rögtön Facebookon leellenőriztük egymást, most erre nincs lehetőség, és marad az izgalomteljes várakozás a randiig. Kicsit a régi időkre emlékeztet, nagyon tetszik."

Kiderült, hogy néhányan a közvetlen családi kapcsolattartáshoz, élmények megosztásához is a platformot használják - különösen, ha távol vannak egymástól.

„Weblapokat kellett időnként felkeresnem - sportoldalak, nso.hu, hoszszabbitas.hu, ezeket kerestem. Nagy szükségem lett volna rá, mert az egyik fiam és a férjem elutaztak, és tudtam, hogy oda töltik fel a képeket az élményeikről.”

„Az anyukám kicsit meg van sértődve, amiért megint faksznizok, és nem használom a családi FB-csoportot (messze élünk egymástól).”

Mivel sokan feed readerként használják a platformot, a felfüggesztéskor szembesültek a filter buborék jelenségével ${ }^{22}$, illetve észlelték az internetes népművészet alkotásainak (GIFek, mémek) hiányát.

21 Ez a visszajelzés a „gyenge kapcsolatok” (Csermely 2005) erejének egyik példája. Az álláskeresés bizonyítottan sikeresebb a közösségi médián fenntartott kapcsolati hálón keresztül, olyannyira, hogy sok munkáltató elsősorban ott hirdeti meg a szabad pozíciókat.

22 A filter buborék (Pariser 2011) azt a mesterséges szűrőt jelenti, amely a saját korábbi online tevékenységeink alapján szűri ki a számunkra relevánsnak tartott tartalmakat, azaz a korábbi kapuőrök helyére a tanuló algoritmusok által vezérelt AI kapuőrök kerülnek. Sokan, például Tufekci (2007), ennek etikai következményeire hívják fel a figyelmet. 
„A poénos képekről, mémekről lemaradok.”

És nem kellett, mert nem botlottam beléjük.”

Tipikus probléma volt még a platformhoz kötött alkalmazásokhoz, illetve magának a platformnak a kiegészítő szolgáltatásaihoz való hozzáférés.

„Egyedül a Facebookkal létrehozott regisztrációk elvesztése fájó (Runtastic, Waze, Airbnb), és kerestem rá megoldást-- sikertelenül.”

„Az első két nap furcsa volt, mert sokat szoktam a gyerekeimnek vásárolni a Market Place-en. Talán ez hiányzik a legjobban.

\section{Veszteségek}

„Ami hiányzik, azok a fotók, a természetfotók. S hiányoznak a Facebook megerösítő lájkjai, egy-egy írásomra, fotómra. Ennek most nincs olyan fóruma az életemben, ahol hasonlóan gyors kommenteket, "tetszik«eket kapnék."

A kódolás során az egyik nehézséget az jelentette, hogyan lehet világosan elkülöníteni a valódinak tekinthető veszteségélményt a veszteségnek tűnő technikai nehézségektől és diszkomfort érzésektől. Ezért veszteségként csak azok a reflexiók kaptak kódot, amelyek vélhetően fontos, máshol ugyanebben a formában nem megélhető, hozzáférhető tartalmakra, kommunikációs lehetőségekre, tevékenységekre vagy épp impulzusokra vonatkoznak.

Sokan vélték úgy, hogy az online közösség számukra a magányérzet oldását is szolgálja.

„Mivel kisgyerekekkel vagyok itthon, egyedül, így hiányoznak ezek a csoportok, úgy érzem, nem változott, nem rendezödött át a társas életem, mivel nem is igazán van jelenleg, hanem inkább kevesebb lett.”

Felbukkant a visszajelzésekben az online közösség identitásmegerősítő, érzelmi impulzust adó ${ }^{23}$ funkciója is.

„Van hiányérzetem mindenképp, hogy ha eszembe jut valami frappáns, akkor nem tudom hirtelen mindenkivel megosztani, de így legalább azokkal meg tudtam osztani, akik igazán közel állnak hozzám.”

De ide sorolható a fizikai távolság leküzdése ${ }^{24}$ és a csoportos kapcsolattartás ${ }^{25}$ sajátos kombinációja is.

„Ami igazán hiányzik, hogy nagyon sok ázsiai barátom van, akikről sok mindent a Facebookon keresztül tudtam meg."

23 Ezt az érzelmi impulzust a tranzakcióanalízis pszichológiai elmélete nyomán szokás pozitív stroke-nak is nevezni (Berne 1968).

$24 \mathrm{Az}$ online jelenlét egyik alapvető sajátossága az idő és tér érzékelésének paradigmatikus változása, miként azt Csótó Mihály (Csótó 2017) is megállapítja. Az online jelenléttel, különösen pedig a mobil eszközök használatával, távolság is relatívvá, folytonosan mozgó variánssá vált, mivel a fizikai tér és jelenlét tere (az identitás megjelenítésének tere) egymástól elkülönül.

25 A szociális médián keresztül fenntartott kapcsolatokkal összefüggésben a csoportos kurkászás (Dunbar 2002) jelenségét szükséges itt megemlíteni. A Dunbar-szám (nagyságrendileg 150 fő) azt az embercsoportot jelöli, amellyel egyidejüleg képesek vagyunk valós, működő kapcsolatot fenntartani. 
„Offline” nyereségek

„Húsz éve még fontos volt rendszeresen leülni egy-egy kávéra, sörre a barátaimmal, átbeszélgetni órákat, ma semmi ilyesmi nincs. Facebook hiján most újra felhívom azokat, akik igazán fontosak, hogy találkozzunk.”

Ehhez a témához azok a mintázatok kerültek, amelyek a felfüggesztéshez kapcsolódó életmódváltozások kísérői voltak. Ezek a visszajelzések a napirendet, tevékenységeket, időbeosztást és/vagy a kapcsolatokat lényegileg érintő reflexiókat tükrözik.

Általános és nem meglepő tapasztalat, hogy a felfüggesztés időszakában az emberi kapcsolatok élőbbé válnak, a résztvevők többet telefonálnak és találkoznak ismerőseikkel. Úgy tűnik, ez részben annak köszönhető, hogy a kapcsolattartás illúziója eltünik, helyébe egy régi/új igény lép.

„Eddig a Facebook görgetése során láttam néhány fotót vagy posztot, ami elég volt bejövő információként, de ezt nem követte a részemröl sem komment, sem más formájú kommunikáció. Most gyakrabban előfordul, hogy én hívok fel valakit vagy küldök üzenetet, hogy érdeklődjek.”

Lényeges különbségnek látszik, hogy az passzív kapcsolattartást aktív cselekvés és a valós térben való találkozások során fókuszáltabb jelenlét és figyelem váltja fel.

„Több olyan ismerösömmel is - régiekkel és újakkal egyaránt - felvettem a kapcsolatot, akár Messengeren, de személyesen is, akikkel eddig nem igazán foglalkoztam, legfeljebb ,lájkoltam’ a Facebookos bejegyzéseiket. Így ez elég jó tapasztalat.”

„Mivel külföldön élek, ez az elsödleges kapcsom az otthoniakhoz, es néha, amikor eszembe jut valaki, ilyenkor rákerestem. Most abban jobb, hogy írtam inkább, ahelyett, hogy csak rápillantsak az adatlapjára.”

„A legmeghatározóbb élmény, hogy a páromat iszonyatosan boldog, hogy a telefonnyomkodás helyett, sokkal többet kommunikálunk.... :)"

„Beszélgettem egy barátommal, aki gyakorlatilag nem használja a FB-oldalát, és ő is azt bizonyítja, hogy van élet a FB nélkül is. Elmentünk sörözni :)"

„Jobban is figyelek azokra, akikkel éppen vagyok."

„Mikor beállt a társalgásokban az a csend, amikor mindenki előveszi a telefonját, nem volt mit néznem, így fel tudtam hívni a többiek figyelmét, hogy amúgy beszélgethetnénk is.”

A visszajelzések szerint jellemző, hogy felértékelődnek azok az ismeretségek és gesztusok, amelyek a platformon kívül is érvényesnek bizonyulnak. „Érdekes volt szembesülni azzal, hogy kik és mikor vették észre, hogy nem vagyok a Facebookon, és hogy találtak elérhetőséget hozzám.”

„Nem vágytam most azokra a köszöntésekre, akik a hírfolyamban látják, hogy szülinapom van. Ettől viszont sokkal meghatóbbá és személyesebbé vált azoknak a jelentkezése, akik írtak, mert őket nem a rendszer emlékeztette, hanem saját maguk:-)”

Sokan felfedezték, hogy a platform kínálta passzív időtöltést addig - tudattalanul - valamilyen erőfeszítést kívánó aktivitás elkerülésére használták. 
„Az az idő, amit otthon töltök, kevésbé töredezetté és nyugodtabbá vált. A házimunkavégzésnek például kimondottan jót tesz, ha nem írok posztokat ahelyett, hogy belekezdenék. ;)”

A felszabadult időt a többség tervszerűen kezdte más tevékenységekre fordítani.

„Az eddigi tapasztalataim: nagyobb céltudatosság, hatékonyság, tér és idő más, «analóg" időtöltések számára. Valamiféle csend is megjelent az életemben, ami egyértelmüen pozitív."

„Rájöttem, mennyi időt pazaroltam el erre. Helyette most olvasok.”

„A könyvem sokkal gyorsabban fogy, mert akár negyedórára is kinyitom.”

„A lefekvéshez készülődés koncentráltabb, a célom az alvás, mindenféle "kitérö» nélkül, illetve többször vettem a kezembe a könyvemet elalvás előtt.”

„Sokkal több a szabadidőm, ami nagyon jól jött, mert ezt tudom tölteni sportolással és nyelvtanulással.”

„Kézimunkázok, szerintem napi szinten legalább egy órát nyertem.”

„Az éves Bibliaolvasási tervemmel is elkezdtem haladni.”

„A hajnali időm a legaktívabb, az most alkotó munkára megy, míg korábban 1-1,5 óra a Facebook olvasására ment.”

„Elkezdtem írni, egyelöre füzetekbe, naplószerüen.”

„Az esti Facebook-pörgetés helyett többször is föztem.”

\section{„Online” nyereségek}

A visszajelzésekből kiviláglik, hogy a résztvevők zöme sokféle online tartalmat fogyaszt, azaz a Facebook a többség számára csak egy platform a sok közül. Ehhez a témához azok a mintázatok tartoznak, amely az online térben a reflektált, tudatos választás szabadságának megélését jelzik.

„Elkezdtem olyan szaklapok után kutatni a neten (politika, filozófia), amikérdeklődési körömbe vágnak, és az ott megjelenő cikkeket olvasni, kijegyzetelni. Régen, azt hiszem, ezt az időt is a Facebookon töltöttem volna, lustaságból, fáradságból, vagy csak azért, mert nehezen tudtam továbblépni az ottani hírfolyamon. Most pedig sokkal többet böngészek, és nött a kedvencek közé besorolt honlapok száma is."

Mivel sokan feed reader-ként használják a platformot, a felfüggesztéskor ők is szembesültek a filter buborék jelenségével.

„Azt hiszem, hogy mindig meg tudtam találni az egészséges egyensúlyt a valóságos és a virtuális világ között, de a Facebook túlságosan leszúkítette nekem a netet egy platformra. Most kezdem újra felfedezni, hogy mennyi tudás és érdekesség, nem utolsósorban pedig szépség van itt felhalmozva - egy Edmund Husserlről szóló tanulmánytól kezdve egészen a világ nagy múzeumaiban található virtuális sétákig, vagy az élő és ingyenes koncertközvetitésekig."

A buborékból való kiszabadulást tehát sokan kifejezett nyereségként élték meg, amely kinyitotta számukra az online világot.

„A világ híreit, történéseit már nem csak a Facebook szürőjén át láttam, más oldalakra is ellátogattam hírekért, illetve mintha szélesedett is volna az ismeretem a hét történései kapcsán.” 
„Szabadidőm eltöltéseként az általam kedvelt hírportálokat böngészem FB helyett."

Ezen a csoporton belül előfordultak, akik értéktelített módon reflektáltak erre a változásra.

„A haszontalan videók nézegetése helyett a nagyvilág híreit olvasgatom.”

„Nem a Facebookot bambulom, így van időm filmet nézni.”

Bár mindössze egyetlen megjegyzésben szerepel, fontosnak tünik, hogy ugyanez a kiszabadulás vonatkozhat akár a saját magunk által keletkeztetett tartalmakra (azaz saját emlékeink filter buborékjára) is.

„Sokkal több régebbi fotót találtam feleségemről és a kisfiamról így, hogy nem a fiókom fotóalbumaiban kerestem őket, hanem más fórumokon (felhőben, Messengeren elküldött üzenetként). Ezek nagyon jó érzéssel töltöttek el.”

A résztvevők új platformokat is felfedeztek, illetve beszámoltak a platformok közötti hangsúlyváltásról is, ami viszont gyakran pótcselekvésként jelent meg előttük.

„Podcast applikációt töltöttem le, azt hallgatom reggelenként FB-görgetés helyett."

„Az Instagram nézegetése megmaradt, és rendszeresebbé vált. Úgy látszik, függöség van, csak átalakult; irányítottabbá, tudatosabbá vált nálam.”

„Mindenesetre úgy érzem, hogy a közösségi oldalakról való leszokás az esetek legkisebb százalékában tud csak egyik napról a másikra zajlani: eleinte csak átcsap a korábban az adott közösségi médián töltött idő valami pótcselekvésbe (nálam ez a Twitter föként, sokkal többet kezdtem el használni, mint korábban, de már kezd újból normalizálódni), amit aztán szintén tudatosan le kell építeni. Nehéz megtalálni az arany középutat.”

„Néha rám tör a közléskényszer, de ezt kezelendő vagy írok néhány afféle egyperces szösszenetet a virtuális íróasztalfiókomnak, vagy indítok egy blogot. Pár millió mellett elfér még egy... :)”

\section{Tudatosság}

„A Facebook mi magunk vagyunk, nem lehet senkire ujjal mutogatni. Egy olyan jelenség, amivel nem tudunk értelmesen mit kezdeni, csak habzsoljuk, és hagyjuk, hogy új dolgokat csöpögtessenek bele a meglévők mellé.”

Ebben a témakódban részletgazdagon jelennek meg az eleve tudatosságra törekvők és új felismerésekre jutók reflexiói: köztük az adattudatosságra, az életvezetésre és az időgazdálkodásra ${ }^{26}$ vonatkozó visszajelzések. Noha a tudatosság mint motívum más témák (nyereségek, érzelmek) kapcsán is felmerül, fontosnak látszott önálló témaként is kódolni és megpróbálni elkülöníteni, amennyire lehetséges - nem tagadva ugyanakkor, hogy a rugalmas interp-

26 Az információs technológia megbontja az idő és a tér korábbi határait” - írja Csótó Mihály (Csótó 2017: 224). A tér és idő fragmentálódálásával, a „minden azonnalivá” válásával a komplex időhasználati formák problematizálják a multitasking és a mikroidő-kihasználás néha nehezen szétválasztható összefüggéseit is. 
retáció a narratív elemzés sajátja. A skála széles a pro és kontra felismerések között. Ide tartozik a tudatosság növelésének igénye és/vagy a (korábban már szintén említett) függőség-élmény azonosítása is.

Az első bejegyzések a Facebookon eltöltött idöre vonatkoztak.

„IPhone készülékem heti jelentése szerint napi 2 óra 26 perccel kevesebbet néztem a telefonom képernyőjét! Valóban ennyi időt töltök naponta a közösségi médiával?”

„A telefonom heti bontásban méri, mennyi időt töltök az interneten, beleértve a FB-ot is. A heti jelentés szerint most 35 százalékkal csökkent ez az idő.”

„Ami meglepett, és megdöbbentő, hogy hányszor nyomok automatikusan a telefonomon napi rutinból a FB app ikonjára. Ahol aztán nem történik semmi persze. De legközelebb megint rányomok:)"

A felismerés néha a mások viselkedésének megfigyeléséből érkezett.

„Elkezdett irritálni, hogy párom sokat lóg rajta, hülyeségeket néz, már látom, mennyire ostoba időtöltes.”

A korábbi kutatásokban ${ }^{27}$ már feltárt jelenség az unalom élménye és a Facebook-használat korrelációja, ami gyakran a mobil eszköz kéznél-lévőségével is összefügg. A résztvevők közül többen maguk is rámutattak erre..

„Szabadidőmben még mindig gyakran kell az unalomüző görgetés helyett más elfoglaltságot kitalálnom.”

„A legrosszabb, hogy nem tudok lefele görgetni unalmamban, és ezért csinálom ezt. Nem akarom unalmamban nyomkodni a telefonomat. Akkor akarom használni, amikor valamit meg akarok nézni, vagy valamit csinálnom kell. Mivel nincsen Facebook, így több Youtube-videót nézek, valamint most az Instagramot piszkálom unalmamban, a következö app, amit letörlök, az az lesz. Annyira rá vagyunk függve a telefonunkra, hogy az ijesztő. Az iskolában mindenki a telefonját nyomkodja. Sokan 45 percig nem bírják ki. Félelmetes.”

A kísérlet alkalmat adott a résztvevőknek a tudatosabb időgazdálkodásra és a figyelemrabló tevékenységek korlátozására, a jelen tudatosabb megélésére.

„Talán annyi változott, hogy a buszon nem nyomkodom a telefonom, hogy mások sokszor értelmetlen megosztásait nézegessem. Még a felmérésre való jelentkezésem előtt már megfordult a fejemben, hogy szükségem van e a száz éve, vagy akár soha nem látott "ismerősök» gyerekeinek, kutyáinak, macskáinak, nyaralásainak, teleléseinek, karácsonyfáinak és egyéb képeinek nézegetésére. Most, hogy nem nézegetem, alapvetően rájöttem, hogy nem.”

27 Az unalom és a Facebook-használat összefüggése szintén egy sokat kutatott téma (például: Lampe et al. 2006), és az elemzők többnyire valamiféle menekülési kényszerre következtetnek: szerintük az unalom elkerülése, a halogatás egyik eszköze lehet a szociális média, ezen belül a Facebook tartalmainak görgetése. A megfigyelést igazolni látszik egy érdekesség: a Facebook-penetráció első nagy hullámakor az Egyesült Államokban egy rágógumi-gyártó, eladásai csökkenését az új „unaloműzőnek” tulajdonítva, egy erre az üzenetre („Make Face Time”) felépített reklámkampányt is indított. (Bővebben: https://www.nytimes.com/2008/09/25/business/media/25adco.html. Utolsó letöltés: 2019. 07. 11.) 
„Egyre jobban élvezem a több szabadidőt, amit a FB nélküli élet nyújt.”

„Mivel nincs Facebookom, nem azt nyomogatom utazás közben, hanem a tájra, az utazás részleteire figyelek.”

Sokan észlelték, hogy a megszokássá vált szüntelen online jelenlét visszaszorítása tágabb értelemben is több erőfeszítést, a szokások tudatos átalakítását igényli.

„Mióta nincs Facebookom, esténként a mobilnetet+wifit is lekapcsolom rendszeresen, hogy ne pittyegjen, úgy érzem, hogy összességében is nagyobb szabadságot élek meg a szociális médiától."

„A nap folyamán rá-rá néztem a telefonomra, és holott tudtam, hogy fel van függesztve, folyamatosan rákattintottam a FB alkalmazásra, és akkor eszméltem, hogy "de hisz deaktiváltam», és el is tettem a telefont, hogy 1-2 órával később újra megismételjem a müveletet :). Ez pedig így ment kb. 3-4 napig. Ebből pedig már tudom, hogy mindenképp megéri ez a kísérlet, hogy legalább ezt levetkőzzem magamról.”

A kísérlet során a platform társas kapcsolódást szolgáló funkciói is új megvilágításba kerültek.

„Kívülről nézve egészen meglepő, hogy az emberi kapcsolatokat mennyire át tudja járni a Facebook. Szinte lehetetlenné vált valóban elengedni valakit, és nem utánanyúlni, figyelemmel követni, akár éveken át is. Nem tudnak (vagy sokkal lassabban képesek) lezárulni, lecsengeni az elmúlónak gondolt kapcsolatok.”

„Most eltüntem, és 2 ember kérdezte meg kb. a 450 volt ismerősöm közül, hol vagyok, ezért miért is maradjak később is fent?"

„Leginkább azon agyalok, hogy a volt 400 ismerösöm vajon észrevette-e, hogy már nem vagyok online, vajon agyalnak-e azon, hogy én miért nem like-olom a másik által agyon-lájkolt képeket, posztokat. Ezek vajon mit gondolnak rólam?”

„Szerintem ha valaki nem használja a Facebookot, sokkal nyitottabbá válik rengeteg irányba, sokkal könnyebben kezdeményez, illetve ápol kapcsolatokat, hiszen nem függ a közösségi médiától. Nem mások életét nézi, van ideje csakis magával foglalkoznia.”

„Megdöbbentő, hogy az emberek információigényét mennyire kielégíti a Facebook, mert ott sokan megosztanak szinte minden részletet az életükről, és egy személyes találkozás esetén nincs igazából beszédtéma, mert a Facebookról mindenki mindent tud. Sajnos azt kell mondanom, hogy visszavágyom a múltba, amikor a Nagymamámmal a padon ülve a szomszéd nénikkel beszélgetve ért véget egy dolgos nap."

A tudatosság témáján belül szintén erős mintázat az önreflexió. Úgy tűnik, ez egyaránt vonatkozhat a mentális és a fizikai státuszra is, illetve közvetlenül magára az identitásra is.

„Tudatosabb rálátásom van önmagamra. Nekem még mindig az önismeret a legkézenfekvőbb tapasztalat, hogy milyen mechanizmusok müködnek bennem... mit mire használok, hogy terelek, mi az, amivel jobb foglalkozni, mint a valósággal. Megszünt egyfajta terelés az életemben, persze okos vagyok, és találok 
mást, de az mind energiát igényel, hogy kitaláljam, és így inkább sokszor hagyom... szóval kreatívabbnak kell lennem."

„Csak most kezdem realizálni, hogy mennyi felesleges bosszúságtól kímélem meg magam azzal, hogy mások, velem nem egyezö értékrenddel bíró személyek posztjait nem látom.”

„Az általános hangulatom továbbra is nagyon jó a FB nélkül. Sokkal tudatosabb vagyok a légzésemre, tartásomra s sokkal kevesebb a megosztási kényszerem is."

„Elkezdett egy FB nélküli identitásom kialakulni.”

Számosan próbáltak meg valamiféle cselekvési tervet is megfogalmazni, több-kevesebb sikerrel.

„Felismertem a változást, és már ott tartok, hogy törölni akarom magam, de belegondolok, és nem tudom, hogy akkor mit nézegethetnék a szabad perceimben, és honnan tudhatnám meg, hogy mi történik a közeli barátaimmal, akikkel nem vagyok mindennapi kapcsolatban. Nehéz kérdés.”

„Newport egyik javaslata a módszerének elsajátításához a social media jelenlét felfüggesztése, így kihasználva a "csendet", kipróbáltam a deep work módszert, amit valóban nagyon hatékonynak találtam, annak ellenére, hogy még tökéletesen nem tudom alkalmazni. Terveim szerint a csendet tovább fogom tartani a kutatás után is, mert szeretném ezt a hatékony munkavégzést a jövőben is kamatoztatni.”

A tudatosság motívuma felszínre hozta a közösségi média müködésének ellentmondásait, diszfunkcióit is, különösen a virtuális tér kommunikációs aspektusaival összefüggésben.

„Adminként rengeteg fenyegetést kaptam, hiszen némítottam vagy éppen kirúgtam a csoport szabályait sorozatosan megsértőket. Mielőtt leléptem volna az Facebookról, eljutottam odáig, hogy a lakóhelyem szerinti csoportban konkrétan leírtam az ilyen fenyegetőknek, hogy mikor, és hol talál. A Facebook nem azt a szerepet tölti be, amire tervezték. Csak megosztja az embereket, nem összehozza.”

„Hiába a név, az arc, sokan úgy viselkednek, ahogy szemtöl-szemben nem tennék. A billentyüzet, a monitor és a távolság egyfajta látszatbátorságot ad nekik, és válogatás nélkül leírnak mindent, nem törődve a másik emberi mivoltával.”

Végül pedig, az utolsó héten sokan távolabbról is rátekintettek a szociális médiára és önmagukra is.

„Nem szeretem, hogy a digitális terek valósága ennyire összefolyik a hétköznapi fizikai valóság értelmezésével is, egyre kevésbé lehet értelmezni a személyes társas kapcsolatainkat is, ha nem vagyunk jártasak a különböző digitális tereken történő eseményekben és viszonyokban, nagyon meghatározó a digitális világ, rá is telepszik a valóságra."

„Talán az instant örömszerzés volt a lényege, a folyton változó tartalom vonzott oda, ki tudta elégíteni a komoly és kevésbé komoly igényeimet is.”

„Önmagában nagyon-nagyon aggályos számomra az a jelenség, amit a Facebook képvisel. Messze nagyobb hordereje van egy sima vállalkozásnál, komolyan belenyúl és átalakít (sok mindent) a társas kapcsolatainktól önmagunkról alkotott véleményig - mindezt kontroll nélkül. Egy hatalmas nagy kísérleti tö- 
meg a felhasználóké, rajtuk pedig szabadon (de lehet mondani így is: gátlástalanul) kísérletezgetnek - kizárólag haszonszerzési célból.”28

\section{Érzések és érzelmek}

Ehhez témakódhoz az egészen személyes vonatkozású reflexiók, a társas kapcsolatok értékelése és átértékelése, valamint az ezekkel kapcsolatos beszámolók kerültek.

Nyugalmasabb, könnyebb, tisztább, csendesebb, kisimultabb - ezek a kulcsszavak, amelyek igen sok visszajelzésben felbukkannak. Sokan szinte úgy beszélnek a csend időszakáról, mintha valamilyen ajándékot kaptak volna, vagy engedélyt egy másik életre.

„Könnyebb, tisztább érzés. Megszünt a «megfigyelés «”.

„A legmeghatározóbb élmény a zaj megszünése. A csend.”

„Egyfajta kisimultságot érzek, nyugodtabb és fókuszáltabb állapot... mivel nem árad felém annyi plusz vagy felesleges információ koordinálatlanul... azt gondolom, most ezt a részét élvezem a legjobban... valóságosabb.”

„Kipihentebbnek és felszabadultabbnak érzem magam.”

„Nem idegesitem fel magam a butaságokon.”

„Néha ránézek a vonaton Facebookozó emberekre, és arra gondolok, hogy milyen boldog vagyok, hogy nem kell, hogy érdekeljen többé random ismeretlenek véleménye. Felszabadító érzés. Nem hiszem, hogy valaha visszatérek."

„Lehet, nevetségesen hangzik, de olyan szabadnak érzem magam.”

„Büszkén léptem ki az oldalról.”

„Nincs hiányérzetem, inkább csak szokatlan az egész. Mint amikor héjastól eszem a kiwit."

„Színesebbnek és nyugodtabbnak érzem most az életet, mert egész más dolgok is beleférnek most már a látóterembe, mint amiket a barátaim Facebookos megosztásaiból, ajánlásaiból korábban megismertem.”

„Összességében sokkal nyugodtabb vagyok és sokkal több mindenre jut időm.”

„Sokkal inkább kezdek magammal foglalkozni, megismerni ki is vagyok valójában, és elkezdtem élvezni az életet.”

„Jó érzés volt...rácsodálkozni a körülöttünk lévő világra, az emberekre az utcán."

Sokat vizsgált jelenség ${ }^{29}$ a Facebook-jelenlét és a szorongás, frusztráció, agresszió, versengés összefüggése. A korábbi eredményeket megerősítik a most kapott visszajelzések is.

28 A felhasználói tudatosság, különösen a közösségi média összefüggésében, szintén szerteágazó kutatások tárgya. Az egyik legnagyobb hatású keretrendszer a kontextuális integritás elmélete (Nissenbaum 2009).

29 Ide kapcsolódó kutatások (például: Tromholt 2016) rendre azt találták, hogy a Facebook elhagyásakor a kiegyensúlyozottság mérhetően növekszik, a frusztráció és a versengési hajlam csökken. Noha a használat (az imázs-építő posztok, a mindennapok „kipolírozott” bemutatása) éppen azt célozná, hogy az önbizalom erősödjön, ennek hatása valójában kontraproduktív, a vizsgálatok szerint. Mások pedig azt igazolják, hogy a személyiség és a beállítódás a digitális identitáshoz kapcsolódó önbizalommal mindkét oksági kapcsolatot tekintve (azaz oda- és visszaható) erős korrelációban van (Tóth és Mirnincs 2014). 
„Bár azt gondoltam, hogy a posztolással feszültségeket vezetek le, most mégis azt érzem: a jelenlegi teljes FB-absztinencia felszabadultabbá tesz, mintha a dolog fordítva müködne: maga a közléskényszer generálta volna a feszült lelkiállapotot?”

„Sokkal kevesebbet foglalkozom mások véleményével (ezelőtt sok bajom volt azzal, hogy túl sokat gondolkodom ezen, szóval ez egy pozitív változás).”

„A minap megfordult a fejemben, hogy lehetséges az, hogy a napi Facebook «ideglelés « erösen csökkentette az ingerküszöbömet.”

„Néha a sok ostobaság felidegesített, így mondhatnám, hogy valamilyen mértékben csökkent a stressz a retardáltfigyelés nélkül.”

A visszajelzésekben megfigyelhető a Facebook-irigység is.

„Mások vacsorájának/párkapcsolatanak/gyerekének/nyaralásának a nézegetése kifejezetten rossz hatással tudott rám lenni, mert annak ellenere, hogy tudom, hogy ez csak a Facebooknak szól, mégis olyan érzést keltenek ezek a posztok, mintha mindenkinek tökéletes élete lenne, és mivel én épp egy elég nehez periódusban vagyok (vagy vagyok túl), ez nem könnyítette meg a saját problémáim helyen kezelését. Szeretném levetkőzni azt a rossz szokásomat, hogy mások általam elképzelt/Facebookon prezentált életéhez hasonlítsam a saját helyzetemet, és Facebook hiányában ez kicsit könnyebb.”

„Rájöttem, mennyire kamu boldogságot sugaroznak ott az emberek. Az, aki állandóan csinosan, sminkelve pózolgat, a hétköznapokban lestrapált anyuka, a sokadik nyaralós képet feltöltő meg hétköznap alig eszik, csak hogy meglegyenek ezek a képek.” fel."

„Nincs az a zavaró tényezö, hogy ki mit mondott rólam, amíg nem néztem

„Furcsa érzés volt rádöbbeni, hogy mások tökéletes kirakatélete frusztrálttá tesz."

„A társadalomnak és vadidegen embereknek való megfelelés, felületes ismerősökkel való versengés... iszonyatos mértékben frusztrált.”

Sokakban erős érzelmeket váltott ki függőségü $k^{30}$ nem várt felismerése is.

„A hét legkülönösebb tapasztalata egyértelmüen az volt, hogy egyik nap azt álmodtam, hogy véletlenül visszaaktiválom a Facebookomat, és ott ülök a gép elött, és csak látom a Facebookot, és csalódott vagyok, hogy nem tartottam be a négy hetet. Elgondolkodtam ezen az álmon, és arra jutottam, hogy félek attól, hogy a közösségi média már túlságosan a böröm alá kúszott, és akármit teszek, függő vagyok.”

30 A Facebook-függőség mérésére a Bergen Facebook Addiction Scale-t alkalmazzák. A szociális médiához kapcsolódó addikció (Dávid és Körmendi 2018) ugyan még nem hivatalosan jegyzett betegség (Andreassen et al. 2012), de a skálát már számos vizsgálatban validálták. Általánosan igazolt, hogy a nők és az érzelmileg labilis kötődésűek hajlamosabbak a negatív hatások alá kerülni, míg a mentálisan stabilak, például (Mecser és Smohai, 2014) a hitüket mélyen megélő vallásos emberek kevésbé. 
„Félek a visszaeséstől, tényleg, hiába érzem jónak, hogy nincs. Nem akarok "veszíteni « a Facebookkal szemben, azt akarom, hogy én irányítsak, és független és szabad legyek."

A pozitív érzelmi témák jellemzően az önrendelkezés visszaszerzéséről szóltak. Néhányan úgy fogalmaztak, mintha valamilyen igazán nagy próbatételen mentek volna keresztül győztesen.

„Tényleg szabadságot érzek egy picit, a munkában egyértelmüen fókuszáltabb vagyok, a magánéletben pedig talán jobban elengedem azokat, akik nincsenek már a közelemben, és arra a néhányra fókuszálok, akik megmaradtak.”

„Egy hét után sokkal jobban érzem magam, hogy nem kell néznem a »kirakat “ történéseit, illetve az önbizalmam is nött a héten. Sokkal bátrabb vagyok, és próbálom tudatosabban és szervezettebben élni a napjaimat."

"Jó tudni, hogy képes vagyok kontrollálni magam, még ha ott is a kísértés."

„Újra megtanultam önmagamban lenni és létezni... csak úgy - mert jó!”

„Felszabadító volt, és büszke vagyok magamra, hogy ismét kibírtam.”

Az utolsó hét összegzéseiben néhol szinte megvilágosodásszerűen kapcsolódnak össze érzelmi és a tudatosságra referáló mintázatok, egészen a nagy elhatározásokig.

„Nagyon örülök, hogy részt vehettem ebben a kutatásban, teljesen megváltoztatta a gondolkodásmódomat és az életstílusomat. Sokkal többet sportolok, nyelveket tanulok és tanulok az érettségire. Általánosságban sokkal boldogabb is vagyok, és a barátaimmal is több időt töltök. Eddig azt hittem, hogy nem nagyon zavar be az életembe a Facebook, de most, hogy nincs, már látom, hogy mekkora hatása volt."

„Kreatívabb lettem és jobban önmagamra, szükségleteimre figyelő.”

„Tudatosabban fogom használni ezt a közösségi színteret, pótcselekvésként semmiképp."

„Remek lecke volt ez a kutatás, ahol megtanultam, hogy ki és mi az igazán fontos az életemben.,

„Nagyon jó böjtformának tartom a Facebook-csendet. Hozzáadott a máshol, más módon való "online" (avagy jelen-) létemhez - tehát teret adott annak, hogy jobban jelen legyek az életemben, az emberekkel, önmagammal és a transzcendenssel való kapcsolataimban. Folytatom a csendet tovább, egészen húsvétig."

„Leszámolok a Facebookkal. Mindenki csak fényezi magát, miközben az élete romokban, minek nézegessem ezt. Elöször csak csökkentettem az ismeröseim számát, aztán kevesebb embert követtem, végül csak a feleségemet, aztán felfüggesztettem a fiókot. Nem hiszem, hogy valaha online leszek megint."

\section{A témák előfordulásának tendenciái hetente}

A kódolási szakaszban hamar szembeötlött, hogy a négy hét során a témák egymáshoz viszonyított gyakorisága erőteljes időbeli tendenciákat mutat. Ezt a sejtést az összesítés csak megerősítette. A 2. számú táblázat adatai a témák 
abszolút gyakoriságát (az említések darabszámát), zárójelben pedig, százalékban kifejezve ${ }^{31}$, az adott héten aktív (visszajelzésők) számához (N) arányosítva jelzik. Az első héten például az akkor aktív 108 résztvevőből 75 fő említette, hogy praktikus ügyekben fennakadásokat okozott számára a fiók felfüggesztése, illetve annak következményei, és 13-an voltak, akik valamilyen őket ért komoly veszteségről számoltak be.

\begin{tabular}{|c|c|c|c|c|c|c|}
\hline \multicolumn{7}{|c|}{$\begin{array}{c}\text { A kódolt témák említési gyakorisága a résztvevők visszajelzéseiben, } \\
\text { heti bontásban }\end{array}$} \\
\hline & Praktikum & $\begin{array}{l}\text { Vesztesé- } \\
\text { gek }\end{array}$ & $\begin{array}{c}\text { „Offline” } \\
\text { nyeresé- } \\
\text { gek }\end{array}$ & $\begin{array}{c}\text { „Online” } \\
\text { nyeresé- } \\
\text { gek }\end{array}$ & Érzelmek & $\begin{array}{l}\text { Tudatos- } \\
\text { ság }\end{array}$ \\
\hline $\begin{array}{l}\text { Első hét } \\
\mathrm{N}=108\end{array}$ & 75 (70\%) & $13(12 \%)$ & $19(18 \%)$ & $\begin{array}{c}5 \\
(5 \%)\end{array}$ & $19(17 \%)$ & $19(18 \%)$ \\
\hline $\begin{array}{c}\text { Második } \\
\text { hét } \\
\mathrm{N}=83\end{array}$ & $36(43 \%)$ & $\begin{array}{c}3 \\
(3,6 \%)\end{array}$ & $\begin{array}{c}7 \\
(8,4 \%)\end{array}$ & $\begin{array}{c}7 \\
(8,4 \%)\end{array}$ & $19(23 \%)$ & $22(26 \%)$ \\
\hline $\begin{array}{c}\text { Harmadik } \\
\text { hét } \\
N=86\end{array}$ & $53(61 \%)$ & $\begin{array}{c}2 \\
(2 \%)\end{array}$ & $10(12 \%)$ & $\begin{array}{c}4 \\
(5 \%)\end{array}$ & $25(30 \%)$ & $16(19 \%)$ \\
\hline $\begin{array}{c}\text { Negyedik } \\
\text { hét } \\
\mathrm{N}=87\end{array}$ & $12(14 \%)$ & $\begin{array}{c}1 \\
(1 \%)\end{array}$ & $\begin{array}{c}3 \\
(3 \%)\end{array}$ & $\begin{array}{c}1 \\
(1 \%)\end{array}$ & $22(25 \%)$ & $28(32 \%)$ \\
\hline
\end{tabular}

2. táblázat: A kódolt témák említési gyakorisága

Látható, hogy a platform elhagyása utáni első napokban a résztvevőknek a mindennapi élet apró, de kényelmi szempontból fontos elemeinek (ezt fedi a „praktikum” témakód) hiánya tünt fel leginkább. Sokakat ért meglepetésként, hogy a zárt csoportokban folytatott információcsere, az események részleteinek (időpont, helyszín) frissítései, az iskolai vagy munkahelyi ügyek, feladatok Facebook-kommunikációja már teljesen átszőtte a mindennapi életük megszervezését, és beszámolóik szerint eleinte nem minden esetben találtak hasonlóan használható platformot vagy csatornát.

A kódolás során talált fenti narratívatendenciákat megerősítette a második hét visszajelzése mellett szereplő feleletválasztós kérdésre adott 83 válasz (2. ábra). A második héten aktív válaszadók több mint kétharmada úgy nyilatkozott, hogy leginkább a hétköznapi tevékenységekhez vagy az eseményekhez kapcsolódó, esetleg a még csoportokban elérhető információk hiányoznak, és

31 A százalékszámításnál a kerekítés szabályai érvényesülnek. 
csak elenyésző számban hiányolták például az élmények, örömök, bosszúságok megosztásának lehetőségét, vagy az ismerősök életének híreit. ${ }^{32}$

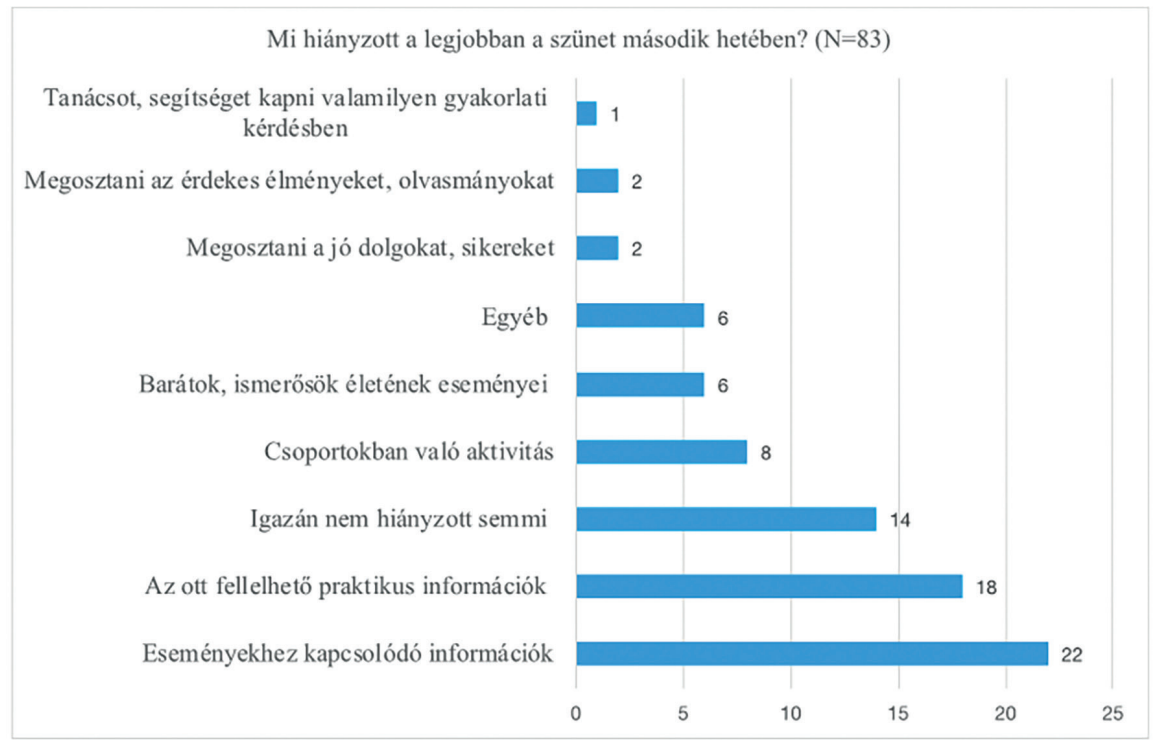

2. ábra: A feleletválasztós kérdésre adott válaszok a második hét utáni visszajelzésben

A négyhetes periódus végére a praktikus nehézségek visszajelzések száma az ötödére csökkent. A többségnek valószínűleg sikerült helyettesítő megoldásokat kidolgoznia az ügyek kezelésére - vagy egyszerüen csak hozzászokott az új helyzethez. Mindeközben csökkent a veszteségélményekről szóló beszámolók száma is, és ezzel párhuzamosan az időtöltés eleinte nyereségként megélt szerkezetváltozását („online és offline nyereségek”) is egyre kevesebben reflektálták, míg az érzelmi, hangulati visszajelzések szaporodtak.

A témák kódolásával megmutatkozott másik látványos tendencia: a tudatosság erősödése, pontosabban a tudatosságra reflektáló visszajelzések számának növekedése. Más szóval az első, kézenfekvő tapasztalatokat követően a résztvevőknek egyszerre sikerült távolabbról, egyfajta objektivitással szemlélni a közösségi médiához való viszonyukat és egyben befelé figyelniük, elcsendesülniük. Ezért a tudatosságot kezdetben aha-élményként megélők fokozatosan a kognitív reflexiók, érvek és tények felé mozdultak el, ami sokak

32 Ez az adat természetesen nem igazolja, csupán támogatja a kvalitatív eredményeket. A kódolt mintázatok tendenciái ugyanis a módszer korlátaiból következően - validálhatóan és egyértelműen - nem azonosíthatóak a hangsúlyokban bekövetkezett változásokkal. (Azaz, hogy például résztvevők valóban kevesebb praktikus nehézséggel szembesültek a negyedik héten, mint az első héten.) Másképpen fogalmazva: nem zárható ki, hogy a nehézségek még a negyedik héten is fennáltak, de az akkor visszajelzők nem tartották szükségesnek ezeket újra megemlíteni. A tendenciák bemutatása mindazonáltal a narratív elv azon hipotézisén alapul, hogy időbeli sorrendnek (azaz, hogy a résztvevő mikor tartja fontosnak megemlíteni a témát) jelentősége van. 
esetében kiterjedt a teljes online jelenlétük felülvizsgálatára is. Ennek részeként például használni kezdtek olyan alkalmazásokat, amelyek az online töltött időt mérik vagy akár az egyes platformokra lebontva korlátozzák is azt.

A két kiugró adatot (azaz az első héten a praktikus nehézségek igen nagy arányát és a negyedik héten a tudatosság és érzelmi reflexiók felerősödését) a 3. és 4. ábra szemlélteti.

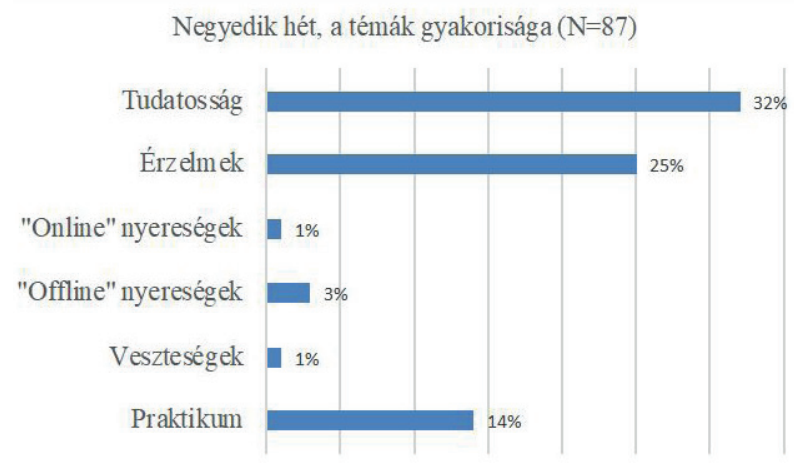

3. ábra: Az elemzés során kódolt hat téma előfordulási gyakorisága az első hét visszajelzéseiben

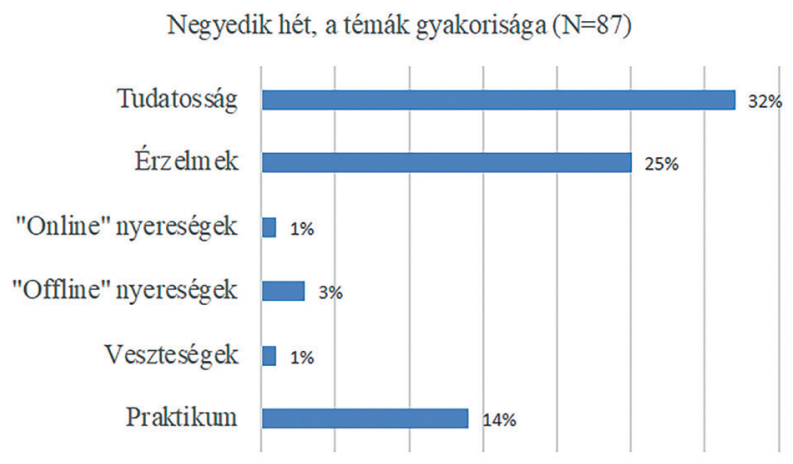

4. ábra: Az elemzés során kódolt hat téma előfordulási gyakorisága a negyedik hét visszajelzéseiben

\section{Összegzés}

Az empirikus kutatásban a Facebook-fiókját felfüggesztő 173 résztvevő viszszajelzéseit elemezve hat nagy témát sikerült azonosítani. A reflexiókon belül fellelt mintázatok megerősítették a Facebook-csend eddig ismert összes sajátosságát: a többi közt a filter buborék észlelését, az inaktivitás időszaká- 
ban pedig a frusztráció és szorongás csökkenését, az énkép stabilizálódását, a társas kapcsolatok személyesebbé és közvetlenebbé válását, az online tevékenységek csökkenését, a nem digitális szintéren zajló időtöltések előtérbe kerülését, a felhasználói tudatosság erősödését, de például a halogatás és az unalom fogalmának újrakeretezését is.

A kutatást záró, a tapasztalatokat összegző kérdőívben kapott válaszok pedig azt jelzik (5. ábra), hogy a többség önmagán is megtapasztalta ezeket a jelenségeket.

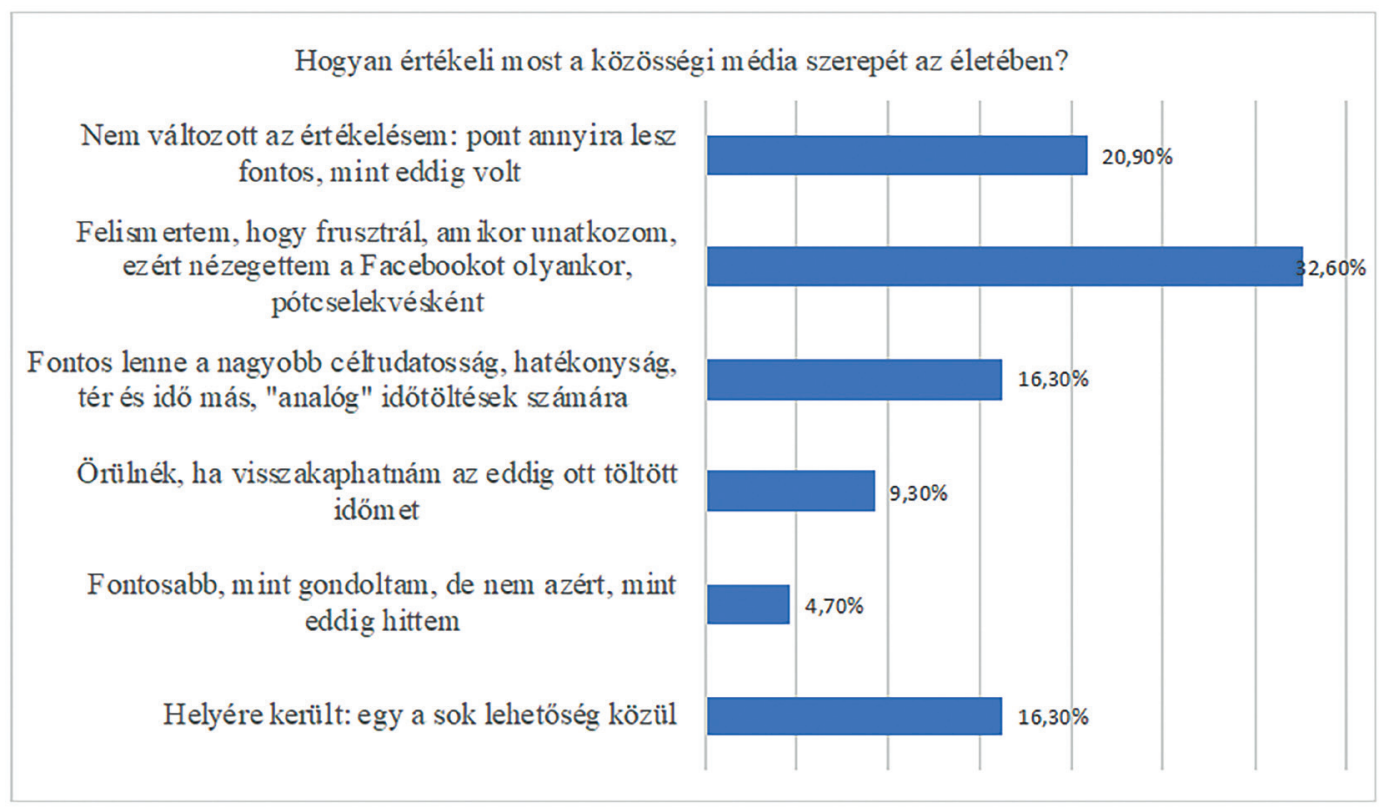

5. ábra: A kutatást záró kérdőív egy feleletválasztós kérdése, a válaszok eloszlása $(\mathrm{N}=87)$

A visszajelzésekben szintén több utalás található arra, hogy a kísérlet során a résztvevők önmaguk számára is hasznos önismereti munkát végeztek. Fontos körülmény, hogy erre többségük valószínűleg mentális értelemben készen is állt, mert már a kutatást megelőzően, eleve erős motivációval, reflexív diszpozícióval rendelkezett ahhoz, hogy a Facebookhoz füződő viszonyát felülvizsgálja. A vizsgálat különlegessége, hogy olyan felhasználóktól gyüjtött adatokat, akik a közösségi médiát zömmel kritikával szemlélik és vélhetően tudatos használatra törekednek - éppen ezért jelentkeztek önkéntesnek. Más kutatásokkal ellentétben azonban itt nem a már inaktív felhasználók nyilatkoztak, hanem olyan, a kísérlet előtt és után aktív felhasználók, akik a szüneteltetést alkalomnak tekintették egyfajta önkísérletre is. Emiatt elköteleződésük nem a hozzájárulásukért kapott javadalmazásból származott, hanem belső motivációjuk hajtotta őket. Sokan tekintettek egyfajta próbatételként, kihívásként a részvételre, és ugyanők általában sikerként, az akaraterő és ki- 
tartás diadalaként élték meg a négyhetes szünet betartását. Ez a körülmény egyfelől az eredmények statisztikai reprezentativitásának korlátja, másfelől azonban képet ad egy sajátos, jól azonosítható felhasználói csoportról. ${ }^{33}$

A kutatás tudományos újdonsága, hogy a narratív elemzésnek köszönhetően a Facebook inaktivitáshoz kötődő felismerések időbeli sorrendje is kimutatható, hiszen a kódokban rögzített, a visszajelzésekben fellelhető témák egymáshoz viszonyított aránya a kísérlet négy hetében szignifikáns változásokat és erőteljes tendenciákat mutatott a praktikus nehézségek kezdeti azonosításától a tudatosság explikációjáig. A kvalitatív elemzés eme következtetéseit az elemzésbe bevont kvantitatív adatok is alátámasztják.

A legfontosabb eredmény, hogy ebben a megvilágításban, ebben az érintetti körben a platform nem is annyira társas kapcsolódási igényeink kielégítésének elsődleges terepeként mutatkozott meg, sokkal inkább mint szokásaink, mindennapjaink olyan része, eszköze, működésmódja, amely az életet, az ügyek intézését, technikai értelemben való kapcsolattartást és információcserét könnyíti meg egy mindenki számára kényelmesen elérhető, és ráadásul (kimagasló penetrációja miatt) mással nehezen helyettesíthető megoldással. Erre lehet következtethetni abból, hogy a résztvevők többsége ezt jelezte vissza leghamarabb hiányérzetként a szünet első hete után. Úgy is fogalmazhatunk, hogy a Facebook-használat költségét például az ott töltött időben mérhetjük, míg elhagyásának költsége, ebben az összefüggésben, a mindennapok megszervezésének időtöbbletigényével is kifejezhető.

A Facebook - általában elsődlegesnek tartott - közösségi és társas funkciója ebben a felhasználói körben sokkal inkább negatív értelmezést kapott a négy héten át tartó reflexiósorozat, a mélyebb megértés során. Úgy tủnik ugyanis, hogy a platformon fenntartott online társas interakciók szüneteltetése csekélyebb hiányérzetet okozott a résztvevőknek, mint amekkora veszteségnek a korábban, az aktív használattal vagy csak passzív jelenléttel eltöltött - a kísérlet végére pedig már sokuk által elpazaroltnak gondolt - idejüket érezték.

A fentiekből látszik, hogy bár az online világot elsősorban a figyelemért folytatott harc terepeként (Csepeli 2014) szokták jellemezni, az idő önállóan is roppant fontos tényező a felhasználói tudatosság kontextusában.

A kutatás eredményeinek számbavétele mindazonáltal nem szükségképpen ért véget a jelen beszámolóval. A meglévő és bárki számára elérhető ${ }^{34}$ nyers

33 A csoport egyik jellemzője, a nagyfokú felhasználói tudatosság, önálló elemzés tárgya is lehetne. Például abban az aspektusban, hogy milyen módon befolyásolja a szociális médiáról szóló nyilvános diskurzus (ennek részeként: a Facebook-irigységről, a függőségről, általában véve a mentális állapotot vizsgáló, széles körben megismerhető kutatási eredmények) azt a diszpozíciót, amely tükröződött a felfüggesztéssel kapcsolatos, a visszajelzésekben is felbukkanó előzetes várakozásokban, illetve biasokban is.

34 A nyers kutatási adatokat (a résztvevők személyes adatainak eltávolításával) a tanulmány szerzője rendelkezésre bocsátja további tudományos elemzések céljából. Az adatok elérhetők itt: http://socialsilence2019.strikingly.com/ 
kutatási adatok lehetőséget teremtenek például további magatartástudományi és szociálpszichológiai vizsgálatokhoz is, hiszen ez az elemzés csak a narratív korpuszban fellelt főbb tendenciák bemutatására és néhány fontos körülmény exponálására vállalkozott, elsősorban kommunikációs szemlélettel.

Ezenkívül, a nagyszámú érintett, a felhasználói tudatosság, és ezzel a belső motivációk erősödése, a digital silence trendjei, valamint az itt nem alkalmazott, de rendelkezésre álló, strukturáltabb online naplózásjellegü, adatfelvételi módszerek, más narratív elemzési technikákkal, illetve sokféle lehetséges fókusszal összekapcsolva izgalmas horizontot nyithatnak a további empirikus kutatások, újabb adatfelvételek és azokhoz kapcsolódó elemzések számára is. Ezekhez a törekvésekhez is inspirációt kívánt nyújtani e tanulmány.

\section{Irodalom}

Allcott, Hunt, et al., „The Welfare Effects Of Social Media”, National Bureau of Economic Research, No. w25514, 2019.

Andreassen, C. S., et al, „Development of a Facebook Addiction Scale”, Psychological. Reports, 110 (2012) 2, pp. 501-517 https://doi.org/10.2466/02.09.18.PR0.110.2.501-517 Utolsó letöltés: 2019 07. 21.

Ariely, Dan, „Payoff: The Hidden Logic That Shapes Our Motivations”, Simon \& Schuster/ TED, 2016.

Baumer, E.P.S. et al., „Limiting, leaving, and (re)lapsing”, Proceedings of the SIGCHI Conference on Human Factors in Computing Systems, ACM, 2013.

Berne, Eric, „Games people play: The psychology of human relationships”, Penguin, United Kingdom, 1968.

Csepeli György, „Szociálpszichológia mindenkiben”, Budapest: Kossuth Kiadó, 2014.

Csótó Mihály, "Rések, átfedések és párhuzamosságok, avagy a mikroidő rövid története”, in Rab Árpád (szerk.) Csomópontok - A digitális kultúra jellemzôi és egymásra hatásuk, Gondolat - Infonia, 2017, 204-242. old.

Dávid Balázs, Körmendi Attila, „Facebook-függőség”, Psychiatria Hungarica, 33. 1 pp. 25-34. , 10 p. (2018) https://medinfo.aeek.hu/index.php/2019/01/09/facebook-fuggoseg-david-balazs-kormendi-attila/ Utolsó letöltés: 2019. 07. 21.

Dhir, Amandeep, et al., „Online social media fatigue and psychological wellbeing - A study of compulsive use, fear of missing out, fatigue, anxiety and depression." International Journal of Information Management 40 (2018) pp. 141-152.

Dunbar, Robin, „The social brain hypothesis.” Foundations in social neuroscience 5.71, (2002) . Forman, James \& Darmschroder, Laura, „Qualitative Content Analysis”, in Jacoby \& Siminoff (eds.): Empirical Methods for Bioethics. Advances in Bioethics, Vol. 11. JAI Press, Oxford. pp. 39-62, 2008, DOI: 10.1016/S1479-3709(07)11003-7.

https://www.academia.edu/23784019/Quitting the use of a habituated hedonic information system a theoretical model and empirical examination of Facebook users Utolsó letöltés: 2019 07. 21. 
Katz, Elihu, Michael Gurevitch, Hadassah Haas, „On the Use of Mass Media for Important Things” American Sociological Review, 38. (1973) pp.164-181.

Krippendorff, Klaus, „Content analysis: An introduction to its methodology”, Sage publications, 2018.

Lampe, Cliff, Nicole Ellison, and Charles Steinfield, „A Face (book) in the crowd: Social searching vs. social browsing" Proceedings of the 2006 20th anniversary conference on Computer supported cooperative work, ACM, 2006.

Luqman, A. et al., „Empirical investigation of Facebook discontinues usage intentions based on SOR paradigm”, Computers in Human Behavior, (2017) 70, pp.544-555.

Mecser Anikó, Smohai Máté, „Virtuális kapcsolati hálók: Facebook-függőség és motiváció öszszefüggései”, in Fülöp József, Mirnics Zsuzsanna, Vassányi Miklós, Kuhn Gabriella Szilvia (szerk.), Kapcsolatban - Istennel és emberrel: Pszichológiai és bölcsészeti tanulmányok, Károli Gáspár Református Egyetem, L’Harmattan Kiadó, 2014, 237-244. old.

Miles, Matthew \& Michael Huberman, „Qualitative data analysis: An expanded sourcebook”, Sage Publications, Thousand Oaks, 1994.

Nissenbaum, Helen, „Privacy In Context: Technology, Policy, And The Integrity Of Social Life”, Stanford Law Books, Stanford, 2009. ISBN 978-0-804-75237-4.

Pariser, Eli, „The Filter Bubble: What the Internet Is Hiding from You”, New York: Penguin Press, 2011. ISBN 978-1-59420-300-8.

Stieger, Simon et al., „Who Commits Virtual Identity Suicide? Differences in Privacy Concerns, Internet Addiction, and Personality Between Facebook Users and Quitters”, Cyberpsychology, Behavior, and Social Networking, 16 (2013) 9, pp. 629-634.

Szűts Zoltán, „Az én nyilvánossága a Facebookon”, E-nyelv.hu Magazin 3, 2013, pp. 1-4., 4 p. http://e-nyelvmagazin.hu/2013/09/10/az-en-nyilvanossaga-a-facebookon/ Utolsó letöltés: 2019 07. 21.

Tóth József, Mirnics Zsuzsanna, „Önértékelési kontingenciák, kötődés és Facebook használat”, Alkalmazott Pszichológia (2014) 133-148 old.

Tromholt, Morten, “The Facebook Experiment: Quitting Facebook Leads to Higher Levels of Well-Being” Cyberpsychology, Behavior, and Social Networking 19.11, 2016, pp. 661-666.

Tufekci, Zeynep, „Can you see me now? Audience and disclosure regulation in online social network sites.” Bulletin of Science, Technology \& Society 28.1, 2008, pp. 20-36.

Turel, Ofir, „Quitting the use of a habituated hedonic information system: a theoretical model and empirical examination of Facebook users.” European Journal of Information Systems 24.4, 2015, pp. 431-446.

Ujhelyi Adrienn, „A Facebook szociálpszichológiája”, Alkalmazott Pszichológia, (2014) 14. szám, 113-132 old.

Ujhelyi Adrienn, Domonkos Katalin, „Hogyhogy nem vagy a Facebookon?: A Facebookot nem használók percepcióinak és motivációinak vizsgálata”, Jel-Kép, (2016) 2., 1-19. old.

Wilson, Robert, Samuel Gosling, Lindsay Graham, „A review of Facebook research in the social sciences”, Perspectives on Psychological Science, 7. (2012) 3. pp.203-220.

York, Chance, Jason Turcotte, "Vacationing from Facebook: Adoption, Temporary Discontinuance, and Readoption of an Innovation”, Communication Research Reports 32.1 (2015) pp. 54-62. 


\section{Függelék}

A kutatáshoz résztvevőnek jelentkező 173 magyar önkéntes demográfiai adatai. ${ }^{35}$

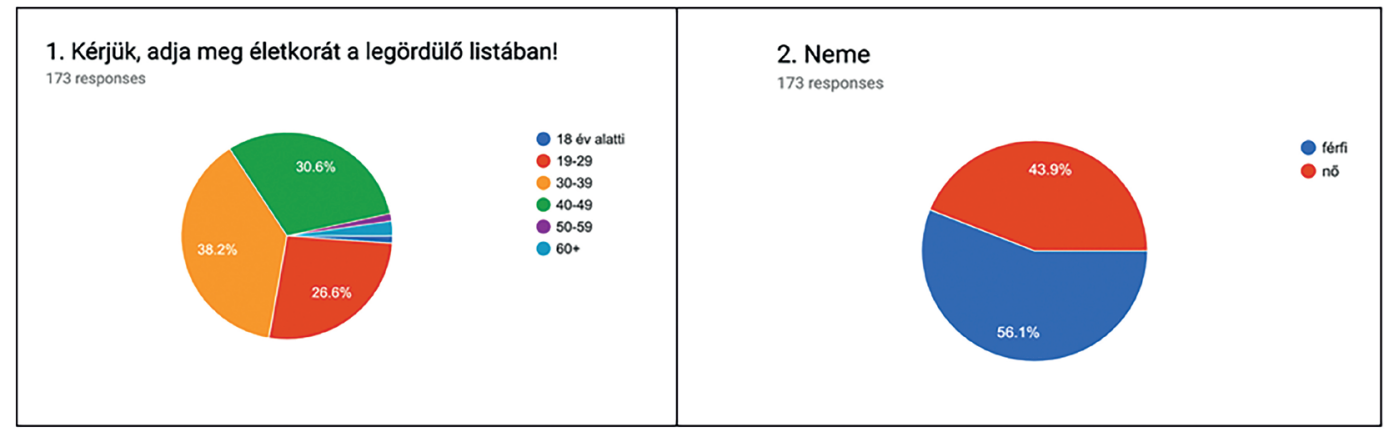

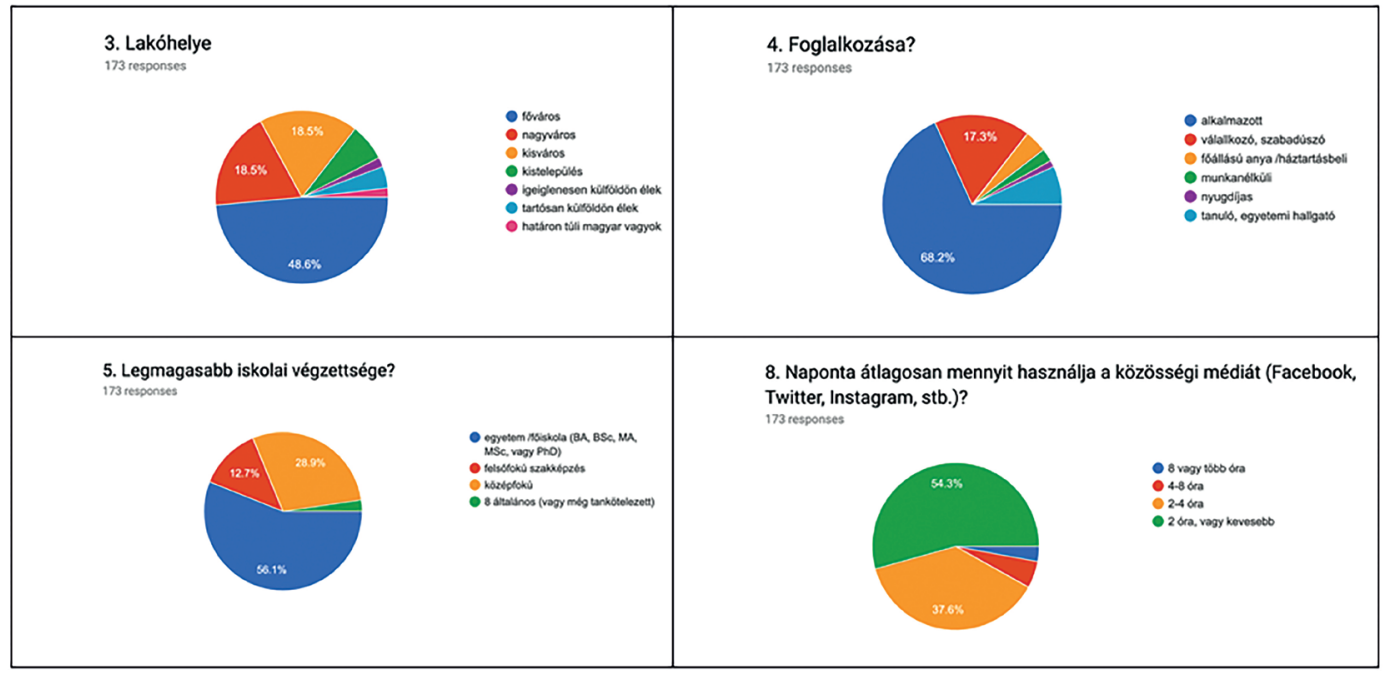

35 A teljes résztvevői minta nem azonos az egyes hetek során visszajelző résztvevőkkel.

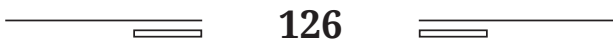

